\title{
Ecology of Acartia tonsa in Apalachicola Bay, Florida, and implications of river water diversion
}

\author{
J. N. Putland*, R. L. Iverson \\ Department of Oceanography, Florida State University, Tallahassee, Florida 32306-4320, USA
}

\begin{abstract}
Acartia tonsa herbivory, carnivory, egg production rate, egg production efficiency, and abundance were studied within various salinity regimes in Apalachicola Bay throughout a $2 \mathrm{yr}$ period. The percent of phytoplankton productivity ingested by A. tonsa ranged from 0 to $24 \%$ (median $0.4 \%$ ). The diet of $A$. tonsa was mixed. On average, $53 \%$ of the diet was composed of phytoplankton. Per capita total ingestion rate averaged $1.1 \pm 1.3( \pm \mathrm{SD}) \mu \mathrm{g} \mathrm{C}$ adult ${ }^{-1} \mathrm{~d}^{-1}$ during winter, peaked to about $6 \mu \mathrm{g} \mathrm{C}$ adult ${ }^{-1} \mathrm{~d}^{-1}$ during summer, and averaged $2.2 \pm 1.8 \mu \mathrm{g} \mathrm{C}$ adult ${ }^{-1} \mathrm{~d}^{-1}$ during summer. A. tonsa ingested the equivalent of $38 \pm 48 \%$ and $120 \pm 93 \%$ of its body carbon during winter and summer, respectively. During summer, per capita total ingestion rate increased below 20 psu. Average egg production rate (EPR) was lower during winter $\left(13 \pm 15\right.$ eggs female $\left.^{-1} \mathrm{~d}^{-1}\right)$ than during summer $\left(28 \pm 24\right.$ eggs female $\left.{ }^{-1} \mathrm{~d}^{-1}\right)$. During summer, EPR peaked between about 4 and $10 \mathrm{psu}$. During winter and summer, egg production efficiency (EPE) peaked between about 8 and 14 psu. Salinity tolerance and biochemical composition of phytoplankton ingested may have influenced EPE. Phytoplankton allocated more carbon to protein and lipid synthesis in lower salinity water. The areal extent of lower $(<20 \mathrm{psu})$ salinity water decreases in Apalachicola Bay during periods when river discharge is low. Therefore, upstream water diversion during summer can be expected to reduce the areal extent of lower $(<20 \mathrm{psu})$ salinity waters where ingestion rate, EPE, and EPR of $A$. tonsa are greatest and where A. tonsa is an important prey for Anchoa mitchilli.
\end{abstract}

KEY WORDS: River discharge $\cdot$ Management $\cdot$ Fisheries $\cdot$ Estuarine $\cdot$ Ecology $\cdot$ Acartia tonsa

\section{INTRODUCTION}

Marine waters with high concentrations of new nitrogen in the euphotic zone favor the growth of phytoplankton with large cell sizes. Under these conditions, trophic structure is modeled by the classical diatom-copepod-fish food chain (Ryther 1969). In contrast, marine waters with low concentrations of new nitrogen in the euphotic zone are characterized by microbial food webs, which are based on phytoplankton with small cell sizes that are grazed primarily by microzooplankton (Legendre \& Rassouladegan 1995). In the microbial food web model, in contrast to the classical food chain model, copepods acquire nutrition from microzooplankton as well as from phytoplankton. Because they have relatively lower phytoplankton productivity and biomass, and a relatively higher number of trophic transfers, microbial food webs are thought to support lower magnitudes of higher trophic level productivity than classical food chains (Riegman et al. 1993, Legendre \& Rassouladegan 1995).

In a variety of estuaries the phytoplankton community is composed primarily of small cells (J. N. Putland \& R. L. Iverson unpubl. data), microzooplankton are the main herbivores (Calbet 2001, Calbet \& Landry 2004), and copepods are omnivorous (Gifford \& Dagg 1988, Kleppel \& Hazzard 2000, Liu et al. 2005). Therefore, although phytoplankton productivity is relatively high in estuaries (McLusky \& Elliot 2004), and estuaries support significant amounts of higher trophic level production, a microbial food web model appears to represent mass and energy flow through estuarine planktonic food webs.

Apalachicola Bay is a productive estuary located in the northern Gulf of Mexico. The high productivity is a 
result of the Apalachicola River delivering freshwater and nutrients to the bay (Livingston 1984, Mortazavi et al. 2000a, 2000b, 2001). Freshwater moderates salinity in Apalachicola Bay, creating habitat for estuarine flora and fauna. Nutrient input supports high levels of phytoplankton productivity (Mortazavi et al. 2000b), which in turn supports the bay's secondary productivity (Chanton \& Lewis 2002). Diversion of water from headwaters of the Apalachicola River during summer has been proposed to satisfy upstream freshwater requirements. The areal extent of lower $(<20 \mathrm{psu})$ salinity water decreases in Apalachicola Bay during periods when river discharge is low (Mortazavi et al. 2001). Therefore, upstream water diversion during summer can be expected to decrease the areal extent of lower salinity water in the bay. Since nutrient concentrations are greatest in lower salinity waters (Mortazavi et al. 2001), we hypothesized that a classical diatom-copepod-fish food chain would characterize planktonic food web structure in high nutrient/low salinity waters, while a microbial food web would characterize planktonic food web structure in low nutrient/high salinity waters of Apalachicola Bay. Water diversion that decreases the areal extent of lower salinity water where nutrient concentrations are high (Mortazavi et al. 2001) and where a classical food chain may predominate, would lead to reduced higher trophic level productivity.

To test this hypothesis we examined the ecology of phytoplankton, microzooplankton, and copepods in Apalachicola Bay. Companion studies examined the ecology of phytoplankton (J. N. Putland \& R. L. Iverson unpubl. data) and microzooplankton (Putland \& Iverson $2007)$ in the bay. In the present study, we tested the hypothesis that Acartia tonsa is the primary herbivore of phytoplankton in high nutrient/low salinity waters and also examined the seasonal- and salinity-related patterns of ingestion, egg production, egg production efficiency, and abundance of $A$. tonsa in Apalachicola Bay. We specifically examined $A$. tonsa because it is the most abundant copepod and the main constituent of the mesozooplankton community in the bay (Edmiston 1979, Marcus 1991). Parameters were examined with respect to salinity in the bay, specifically during summer when river diversion has been proposed. We chose to examine parameters with respect to salinity, as opposed to station locations, because salinity and nutrient concentrations at specific stations are highly variable due to daily varia-

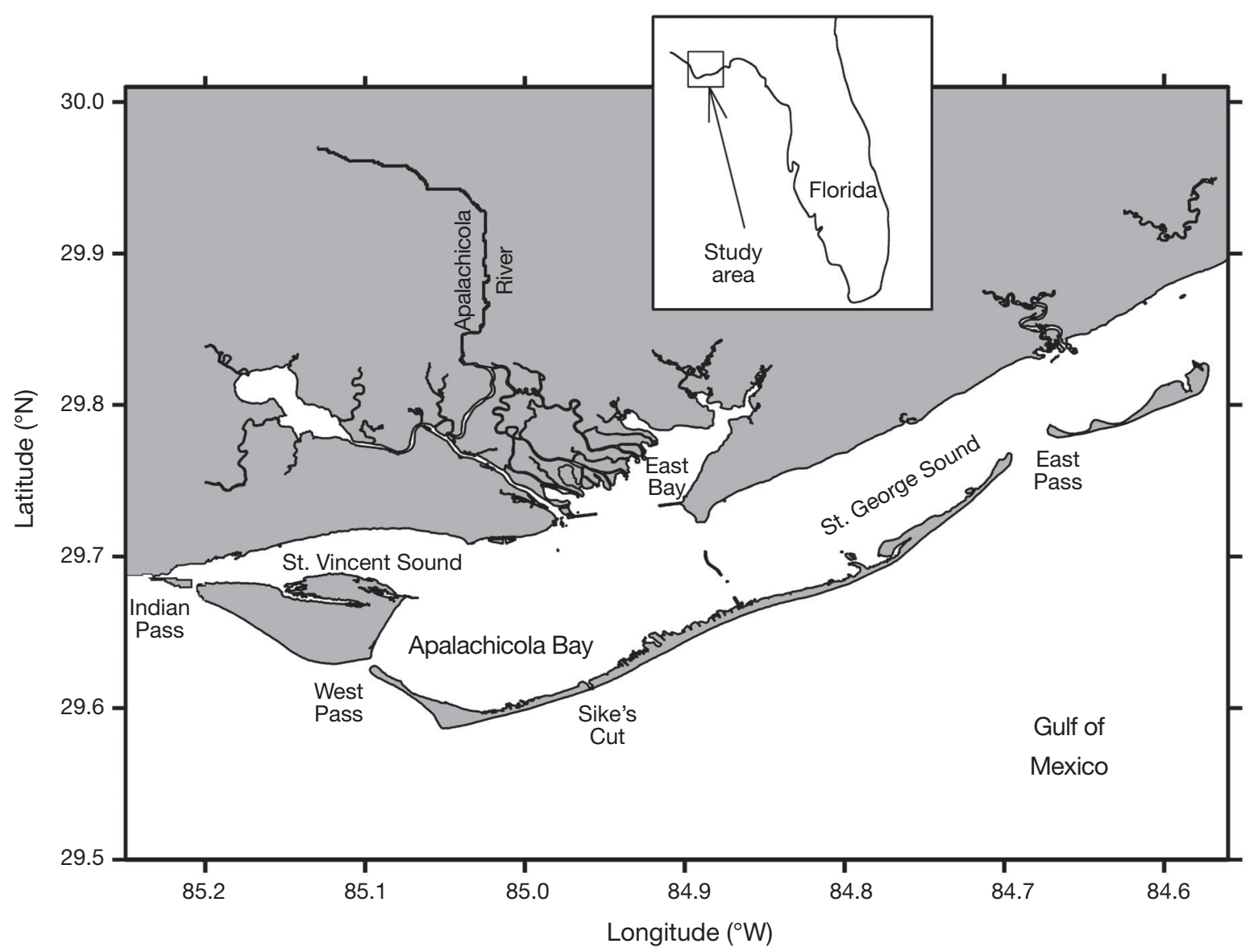

Fig. 1. Apalachicola Bay, Florida 
tions in river flow, wind speed, and tides. Moreover, because reduced river discharge decreases the areal extent of lower salinity water in Apalachicola Bay, we wanted to determine the relationship between biological parameters and salinity to help predict the effect that reduced river discharge will have on the ecological configuration of the bay. It was beyond the scope of this study to determine whether salinity per se influences the biological parameters examined.

\section{MATERIALS AND METHODS}

Physical environment. The physical attributes of Apalachicola Bay (Fig. 1) have been described by Livingston (1984). The bay is an estuary that represents the largest area of the Apalachicola Bay system. It is bounded by barrier islands (St. Vincent, St. George, and Dog Island) to the south and west and separated from St. George Sound by a submerged shoal. Exchange between bay and Gulf of Mexico waters occurs through St. George Sound and openings (East Pass, Sikes Cut, West Pass, Indian Pass) through the barrier islands. Water moves predominantly from the east into St. George Sound and out to the Gulf of Mexico through West Pass. Residence time of water ranges from 2 to $12 \mathrm{~d}$ (Mortazavi et al. 2000a). The average depth of Apalachicola Bay is between 2 and $3 \mathrm{~m}$, and as a result of wind and tides, which are diurnal to semidiurnal with about 0.1 to $0.2 \mathrm{~m}$ range, waters are generally well mixed. The Apalachicola River discharge is the largest in Florida and is the main source of freshwater to the bay. Headwaters of the Apalachicola River are formed at Lake Seminole where waters from the Flint and Chattahoochee rivers meet. River flow typically peaks during spring and is minimal during summer. Annual average flow is about $665 \mathrm{~m}^{3} \mathrm{~s}^{-1}$. River flow is closely related to precipitation in the state of Georgia and is considered the main determinant of salinity in the estuary.

Sampling. Samples were collected monthly from Apalachicola Bay throughout 2003 and 2004 (Table 1). We did not sample from fixed station locations. Instead, on each collection date, water was sampled from oligo-, meso-, and polyhaline portions of the bay. Samples were generally collected in the morning without reference to tidal cycle. Water samples were collected from surface to $0.5 \mathrm{~m}$ depth with a darkened carboy. Immediately after collection, water was sub-sampled from the carboy for phytoplankton. The remainder of the water collected was used for grazing experiments. Temperature and salinity were measured at $0.5 \mathrm{~m}$ depth intervals throughout the water column with a $\mathrm{YSI}^{\circledR}$ salinometer.

Copepods were collected with a conical $202 \mu \mathrm{m}$ nylon mesh net equipped with a closed cod end. The
Table 1. Sampling dates, salinity $(\mathrm{S}, \mathrm{psu})$, temperature $\left(\mathrm{T},{ }^{\circ} \mathrm{C}\right)$, latitude (Lat) and longitude (Long) in Apalachicola Bay where ingestion (IR) and egg production rates (EPR) were determined for Acartia tonsa

\begin{tabular}{|c|c|c|c|c|c|c|}
\hline Date & S & $\mathrm{T}$ & Lat & Long & IR & EPR \\
\hline \multicolumn{7}{|l|}{2003} \\
\hline 29 Jan & $\begin{array}{r}6.7 \\
21.9 \\
2.2\end{array}$ & $\begin{array}{l}10.2 \\
11.2 \\
10.8\end{array}$ & $\begin{array}{l}29^{\circ} 40.0^{\prime} \\
29^{\circ} 38.3^{\prime} \\
29^{\circ} 43.8^{\prime}\end{array}$ & $\begin{array}{l}84^{\circ} 59.6^{\prime} \\
85^{\circ} 05.3^{\prime} \\
84^{\circ} 56.7^{\prime}\end{array}$ & $\checkmark$ & $\begin{array}{l}\checkmark \\
\checkmark \\
\checkmark\end{array}$ \\
\hline 07 May & $\begin{array}{r}29.9 \\
14.5 \\
7.8\end{array}$ & $\begin{array}{l}26.1 \\
26.8 \\
27.4\end{array}$ & $\begin{array}{l}29^{\circ} 38.1^{\prime} \\
29^{\circ} 39.1^{\prime} \\
29^{\circ} 40.6^{\prime}\end{array}$ & $\begin{array}{l}85^{\circ} 05.3^{\prime} \\
84^{\circ} 55.7^{\prime} \\
84^{\circ} 55.9^{\prime}\end{array}$ & & $\begin{array}{l}\checkmark \\
\checkmark \\
\checkmark\end{array}$ \\
\hline 28 May & $\begin{array}{r}9.7 \\
29.8 \\
2.9\end{array}$ & $\begin{array}{l}25.6 \\
26.3 \\
25.6\end{array}$ & $\begin{array}{l}29^{\circ} 37.8^{\prime} \\
29^{\circ} 46.5^{\prime} \\
29^{\circ} 41.9^{\prime}\end{array}$ & $\begin{array}{l}85^{\circ} 02.9^{\prime} \\
84^{\circ} 41.2^{\prime} \\
84^{\circ} 54.6^{\prime}\end{array}$ & & $\begin{array}{l}\checkmark \\
\checkmark \\
\checkmark\end{array}$ \\
\hline 04 Jun & $\begin{array}{l}10.1 \\
17.7 \\
35.0\end{array}$ & $\begin{array}{l}25.8 \\
26.4 \\
26.2\end{array}$ & $\begin{array}{l}29^{\circ} 42.1^{\prime} \\
29^{\circ} 40.0^{\prime} \\
29^{\circ} 38.7^{\prime}\end{array}$ & $\begin{array}{l}84^{\circ} 52.8^{\prime} \\
84^{\circ} 59.6^{\prime} \\
85^{\circ} 04.8^{\prime}\end{array}$ & $\begin{array}{l}\checkmark \\
\checkmark \\
\checkmark\end{array}$ & \\
\hline $09 \mathrm{Jul}$ & $\begin{array}{r}4.8 \\
11.9 \\
23.8\end{array}$ & $\begin{array}{l}30.4 \\
30.9 \\
30.7\end{array}$ & $\begin{array}{l}29^{\circ} 42.1^{\prime} \\
29^{\circ} 43.4^{\prime} \\
29^{\circ} 45.4^{\prime}\end{array}$ & $\begin{array}{l}84^{\circ} 52.8^{\prime} \\
84^{\circ} 48.4^{\prime} \\
84^{\circ} 41.0^{\prime}\end{array}$ & $\begin{array}{l}\checkmark \\
\checkmark \\
\checkmark\end{array}$ & $\begin{array}{l}\checkmark \\
\checkmark \\
\checkmark\end{array}$ \\
\hline 05 Aug & $\begin{array}{r}11.9 \\
28.5 \\
1.2\end{array}$ & $\begin{array}{l}29.4 \\
29.8 \\
28.8\end{array}$ & $\begin{array}{l}29^{\circ} 42.6^{\prime} \\
29^{\circ} 45.5^{\prime} \\
29^{\circ} 40.9^{\prime}\end{array}$ & $\begin{array}{l}84^{\circ} 53.6^{\prime} \\
84^{\circ} 40.8^{\prime} \\
84^{\circ} 53.7^{\prime}\end{array}$ & $\begin{array}{l}\checkmark \\
\checkmark \\
\checkmark\end{array}$ & $\begin{array}{l}\checkmark \\
\checkmark \\
\checkmark\end{array}$ \\
\hline 08 Oct & $\begin{array}{l}17.7 \\
29.7 \\
11.0\end{array}$ & $\begin{array}{l}25.0 \\
25.0 \\
24.9\end{array}$ & $\begin{array}{l}29^{\circ} 40.7^{\prime} \\
29^{\circ} 39.8^{\prime} \\
29^{\circ} 43.3^{\prime}\end{array}$ & $\begin{array}{l}85^{\circ} 70.7^{\prime} \\
84^{\circ} 56.4^{\prime} \\
84^{\circ} 56.8^{\prime}\end{array}$ & $\begin{array}{l}\checkmark \\
\checkmark \\
\checkmark\end{array}$ & $\begin{array}{l}\checkmark \\
\checkmark \\
\checkmark\end{array}$ \\
\hline 22 Oct & $\begin{array}{r}29.8 \\
19.9 \\
9.3\end{array}$ & $\begin{array}{l}22.9 \\
23.2 \\
23.5\end{array}$ & $\begin{array}{l}29^{\circ} 45.1^{\prime} \\
29^{\circ} 41.4^{\prime} \\
29^{\circ} 42.1^{\prime}\end{array}$ & $\begin{array}{l}84^{\circ} 44.7^{\prime} \\
84^{\circ} 51.1^{\prime} \\
84^{\circ} 58.6^{\prime}\end{array}$ & & $\begin{array}{l}\checkmark \\
\checkmark \\
\checkmark\end{array}$ \\
\hline $26 \mathrm{Nov}$ & $\begin{array}{l}31.3 \\
22.3 \\
12.7\end{array}$ & $\begin{array}{l}18.0 \\
17.3 \\
17.5\end{array}$ & $\begin{array}{l}29^{\circ} 45.3^{\prime} \\
29^{\circ} 41.6^{\prime} \\
29^{\circ} 40.9^{\prime}\end{array}$ & $\begin{array}{l}84^{\circ} 44.4^{\prime} \\
84^{\circ} 50.1^{\prime} \\
84^{\circ} 55.4^{\prime}\end{array}$ & $\begin{array}{l}\checkmark \\
\checkmark \\
\checkmark\end{array}$ & $\begin{array}{l}\checkmark \\
\checkmark \\
\checkmark\end{array}$ \\
\hline $02 \mathrm{Dec}$ & $\begin{array}{l}20.4 \\
17.2 \\
11.1\end{array}$ & $\begin{array}{l}13.8 \\
13.8 \\
14.2\end{array}$ & $\begin{array}{l}29^{\circ} 42.9^{\prime} \\
29^{\circ} 41.4^{\prime} \\
29^{\circ} 41.8^{\prime}\end{array}$ & $\begin{array}{l}84^{\circ} 48.9^{\prime} \\
84^{\circ} 50.9^{\prime} \\
84^{\circ} 57.8^{\prime}\end{array}$ & & $\begin{array}{l}\checkmark \\
\checkmark \\
\checkmark\end{array}$ \\
\hline $\begin{array}{l}\mathbf{2 0 0 4} \\
\text { 21 Jan }\end{array}$ & 32.5 & 13.5 & $29^{\circ} 46.5^{\prime}$ & $84^{\circ} 41.4^{\prime}$ & $\checkmark$ & $\checkmark$ \\
\hline 28 Jan & $\begin{array}{l}32.9 \\
19.5 \\
10.8\end{array}$ & $\begin{array}{l}15.3 \\
14.1 \\
14.1\end{array}$ & $\begin{array}{l}29^{\circ} 36.6^{\prime} \\
29^{\circ} 37.7^{\prime} \\
29^{\circ} 42.1^{\prime}\end{array}$ & $\begin{array}{l}84^{\circ} 57.1^{\prime} \\
84^{\circ} 58.1^{\prime} \\
84^{\circ} 52.8^{\prime}\end{array}$ & $\begin{array}{l}\checkmark \\
\checkmark \\
\checkmark\end{array}$ & $\begin{array}{l}\checkmark \\
\checkmark \\
\checkmark\end{array}$ \\
\hline 01 Mar & $\begin{array}{r}30.8 \\
6.3 \\
12.8 \\
23.3\end{array}$ & $\begin{array}{l}13.5 \\
15.1 \\
14.9 \\
14.3\end{array}$ & $\begin{array}{l}29^{\circ} 39.9^{\prime} \\
29^{\circ} 41.5^{\prime} \\
29^{\circ} 41.1^{\prime} \\
29^{\circ} 39.5^{\prime}\end{array}$ & $\begin{array}{l}84^{\circ} 58.2^{\prime} \\
84^{\circ} 57.7^{\prime} \\
84^{\circ} 58.0^{\prime} \\
84^{\circ} 57.2^{\prime}\end{array}$ & $\checkmark$ & $\checkmark$ \\
\hline 26 Apr & $\begin{array}{l}31.8 \\
23.6 \\
12.3\end{array}$ & $\begin{array}{l}24.5 \\
25.1 \\
24.9\end{array}$ & $\begin{array}{l}29^{\circ} 42.0^{\prime} \\
29^{\circ} 41.5^{\prime} \\
29^{\circ} 43.8^{\prime}\end{array}$ & $\begin{array}{l}84^{\circ} 49.1^{\prime} \\
84^{\circ} 54.5^{\prime} \\
84^{\circ} 55.9^{\prime}\end{array}$ & & $\begin{array}{l}\checkmark \\
\checkmark \\
\checkmark\end{array}$ \\
\hline 17 May & $\begin{array}{r}23.7 \\
11.9 \\
6.9\end{array}$ & $\begin{array}{l}26.6 \\
26.1 \\
26.8\end{array}$ & $\begin{array}{l}29^{\circ} 41.4^{\prime} \\
29^{\circ} 41.6^{\prime} \\
29^{\circ} 42.7^{\prime}\end{array}$ & $\begin{array}{l}85^{\circ} 01.1^{\prime} \\
85^{\circ} 09.5^{\prime} \\
84^{\circ} 58.7^{\prime}\end{array}$ & $\checkmark$ & $\begin{array}{l}\checkmark \\
\checkmark\end{array}$ \\
\hline $13 \mathrm{Jul}$ & $\begin{array}{r}33.6 \\
17.7 \\
9.6 \\
0.6\end{array}$ & $\begin{array}{l}30.3 \\
29.8 \\
30.3 \\
29.9\end{array}$ & $\begin{array}{l}29^{\circ} 36.3^{\prime} \\
29^{\circ} 40.5^{\prime} \\
29^{\circ} 41.6^{\prime} \\
29^{\circ} 43.2^{\prime}\end{array}$ & $\begin{array}{l}85^{\circ} 28.8^{\prime} \\
84^{\circ} 59.9^{\prime} \\
84^{\circ} 58.7^{\prime} \\
84^{\circ} 58.7^{\prime}\end{array}$ & $\begin{array}{l}\checkmark \\
\checkmark \\
\checkmark\end{array}$ & $\begin{array}{l}\checkmark \\
\checkmark \\
\checkmark\end{array}$ \\
\hline 17 Aug & $\begin{array}{r}16.8 \\
27.2 \\
5.6 \\
3.7\end{array}$ & $\begin{array}{l}29.6 \\
29.1 \\
29.6 \\
29.4\end{array}$ & $\begin{array}{l}29^{\circ} 37.7^{\prime} \\
29^{\circ} 41.7^{\prime} \\
29^{\circ} 41.7^{\prime} \\
29^{\circ} 42.1^{\prime}\end{array}$ & $\begin{array}{l}84^{\circ} 58.1^{\prime} \\
84^{\circ} 49.6^{\prime} \\
84^{\circ} 58.0^{\prime} \\
84^{\circ} 58.6^{\prime}\end{array}$ & & $\begin{array}{l}\checkmark \\
\checkmark \\
\checkmark \\
\checkmark\end{array}$ \\
\hline 05 Oct & $\begin{array}{r}26.3 \\
19.5 \\
12.1 \\
3.4\end{array}$ & $\begin{array}{l}27.0 \\
26.7 \\
27.1 \\
25.8\end{array}$ & $\begin{array}{l}29^{\circ} 43.4^{\prime} \\
29^{\circ} 41.6^{\prime} \\
29^{\circ} 41.4^{\prime} \\
29^{\circ} 41.5^{\prime}\end{array}$ & $\begin{array}{l}84^{\circ} 48.4^{\prime} \\
84^{\circ} 49.9^{\prime} \\
84^{\circ} 57.2^{\prime} \\
84^{\circ} 58.7^{\prime}\end{array}$ & $\begin{array}{l}\checkmark \\
\checkmark \\
\checkmark\end{array}$ & $\begin{array}{l}\checkmark \\
\checkmark \\
\checkmark \\
\checkmark\end{array}$ \\
\hline
\end{tabular}


net had a 6:1 filtering area to mouth area. The net was towed horizontally for short periods $(<2 \mathrm{~min})$ filtering water from surface to $0.5 \mathrm{~m}$ depth. Acartia tonsa specimens from one tow were used for grazing and/or egg production experiments. Animals were gently rinsed into a cooler containing seawater collected from about $0.5 \mathrm{~m}$. Specimens from another tow were preserved in acid Lugol's (10\% final concentration) and used to estimate the abundance of $A$. tonsa . Volume filtered was estimated using a General Oceanics flowmeter mounted on the inside of the net. Another General Oceanics flowmeter was mounted on the outside of the net to estimate net filtration efficiency. Abundances of adult (males and females) $A$. tonsa were estimated only for tows where filtration efficiency was $\geq 50 \%$. Of all tows conducted, $22 \%$ were discarded because the filtration efficiency was below $50 \%$. Lugol's samples were split with a Folsom plankton splitter between 2 to 5 times, after which about 300 adult $A$. tonsa specimens were counted per sample. A. tonsa individuals were counted with an Olympus stereomicroscope within $1 \mathrm{wk}$ of collection. The abundance was calculated as:

$$
\frac{\text { Number } \times(\text { fraction of original sample })^{-1}}{\text { Volume filtered (l) }}
$$

Acartia tonsa grazing. Prior to conducting grazing (and egg production) studies, all equipment that would contact seawater was soaked in $10 \%$ hydrochloric acid for a few days. Afterward, equipment was thoroughly rinsed and then soaked in Nanopure water for several days. Nitrile gloves were worn during all water handling procedures.

The particle removal method (Frost 1972) was used to assess adult Acartia tonsa grazing on particles $>5$ $\mu \mathrm{m}$. The $5 \mu \mathrm{m}$ size limit was chosen because adult $A$. tonsa is not effective at clearing particles $<5 \mu \mathrm{m}$ in size (Berggreen et al. 1988). Grazing experiments were performed with seawater collected with a darkened polycarbonate carboy from a depth of about $0.5 \mathrm{~m}$. Within $4 \mathrm{~h}$ of collection, carboys containing the seawater and coolers with $A$. tonsa were transported to the Florida State University (FSU) Edward Ball Marine Laboratory. Upon arrival, seawater $(<202 \mu \mathrm{m})$ was added to 11 incubation bottles through silicon tubing that was equipped with $202 \mu \mathrm{m}$ Nitex screening. The silicon tubing was kept submerged below the waterline in the bottles to reduce damage to delicate protists. Eight 11 bottles were filled with <202 $\mu$ m seawater per station. Two bottles were used to acclimate copepods, 2 bottles were used for 'time zero samples', and 4 bottles were used for 'time final samples' (two for controls and 2 for treatments). About 5 to 20 adult copepods (males and females) were added to each acclimation bottle. To facilitate capture of live copepods, animals were anaesthetized with small amounts (0.01 $\mathrm{mg} \mathrm{ml}^{-1}$ seawater) of MS222 (3-aminobenzoic acid ethyl ester) for no more than $10 \mathrm{~min}$. Experiments with adult Acartia tonsa fed Rhodomonas salina demonstrated that this amount and exposure time to MS222 did not significantly affect clearance rate.

Since nitrogen limits phytoplankton productivity throughout most of Apalachicola Bay during summer (Fulmer 1997), inorganic nitrogen (as ammonium chloride) was added to all incubation bottles to ensure that prey growth did not become nitrogen limited and to avoid calculating negative grazing rates due to nutrient enrichment from copepod excretion during the course of the incubations. Enough ammonium chloride was added to bottles to elevate ammonium concentrations to those found in the river. Since nutrient analyses were not synchronised with sampling, we determined the enrichment based on the difference between ammonium concentrations in the river and that at a station with similar salinity for the previous month.

All bottles were placed on a plankton wheel ( 0.5 rpm) and incubated in an outdoor incubator flushed continually with seawater from Apalachicola Bay. Since surface temperature and salinity were not related at any sample time (see 'Results'), bottles were incubated at the same temperature on each sampling date. Incident irradiance was attenuated with neutral density screening to simulate the light energy from the collection site. After an acclimation period of about $18 \mathrm{~h}$, copepods were transferred from acclimation bottles to treatment bottles. To transfer animals, the contents of acclimation bottles were filtered through a $202 \mu \mathrm{m}$ Nitex screen. Filtered copepods were washed into a dish of filtered seawater. Copepods that were alive were transferred to treatment bottles using a wide bore pipette. Samples were taken from the 'time zero' bottles for chlorophyll a measurement and heterotrophic protist estimation after the acclimation period ('time zero samples'). Treatment bottles were placed back on the plankton wheel and incubated for about $24 \mathrm{~h}$. After incubation, copepods were removed from the bottles by filtering the contents through a $202 \mu \mathrm{m}$ Nitex screen. Filtered copepods were washed into a dish of filtered seawater. Copepods that were alive were counted. Copepods were preserved in acid Lugol's (10\% final concentration) and counted immediately. Samples were taken from the control and treatment bottles for chlorophyll a measurement and heterotrophic protist estimation ('time final samples'). These latter samples were used to estimate ingestion of autotrophic and heterotrophic carbon. Any mixotrophs ingested by the copepods were aggregated in our estimate of autotrophic carbon ingested.

Seawater for chlorophyll a analysis was filtered through $47 \mathrm{~mm}$ GF/F filters at $<117 \mathrm{~mm} \mathrm{Hg}$ vacuum. 
Seawater was also filtered through $47 \mathrm{~mm}$ diameter $5 \mu \mathrm{m}$ Poretics polycarbonate filters at $<117 \mathrm{~mm} \mathrm{Hg}$ vacuum to estimate the portion of photosynthetic cells that was $>5 \mu \mathrm{m}$. Filters were stored in darkness at $-20^{\circ} \mathrm{C}$ and analyzed within $1 \mathrm{wk}$ of sample collection. Chlorophyll a was extracted from filters in $90 \%$ acetone for about $24 \mathrm{~h}$ at $-20^{\circ} \mathrm{C}$. The concentration of chlorophyll a was measured fluorometrically with a Model 10 Turner Designs ${ }^{\circledR}$ fluorometer equipped with filter sets for optimal sensitivity of chlorophyll $a$ in the presence of chlorophyll $b$ (Welschmeyer 1994).

Samples for the analysis of heterotrophic flagellates 5 to $20 \mu \mathrm{m}$ in size were preserved in glutaraldehyde ( $2 \%$ final concentration) and stored in darkness at $4{ }^{\circ} \mathrm{C}$ (Gifford \& Caron 2000). Flagellates were enumerated within 1 mo of sample collection. Samples were filtered (<117 mm Hg vacuum) onto $5 \mu \mathrm{m}$ Poretics polycarbonate filters and stained with Acridine Orange (1\% final concentration) (Sherr et al. 1993). Filters were mounted with Cargille's type B immersion oil onto glass slides. A BH Olympus ${ }^{\circledR}$ epifluorescence microscope equipped with a blue/UV excitation filter set (U-M546, excitation 400 to $410 \mathrm{~nm}$; emission 455 to $700 \mathrm{~nm}$ ) was used to visualize cells. Cells that lacked red autofluorescence, indicative of chlorophyll $a$, were counted at a total magnification of $\times 1875$. For each filter, at least 100 heterotrophic cells were counted in either transects or in a minimum of 10 random fields (Hobro \& Willen 1977).

Samples for the analysis of heterotrophic flagellates $>20 \mu \mathrm{m}$ in size and total heterotrophic ciliates were preserved in acid Lugol's ( $2 \%$ final concentration) and stored in darkness at $4^{\circ} \mathrm{C}$ (Gifford \& Caron 2000). Samples were enumerated within 1 mo of collection. Samples $(10$ to $50 \mathrm{ml}$ ) were settled for $24 \mathrm{~h}$ in Utermohl settling chambers. Cells were counted through phase contrast light microscopy at a total magnification of $\times 200$ with an inverted Wild ${ }^{\circledR}$ microscope. If protists could not be identified in Lugol's samples, then their trophic mode (i.e. auto- or heterotrophic) was determined by examining glutaraldehyde samples with epifluorescence microscopy. For each settled sample, transects were counted until at least 100 heterotrophic cells were counted (Hobro \& Willen 1977).

Grazing calculations. Feeding rates on prey were determined with equations of Frost (1972). The percentage of phytoplankton potential production $\left(\% P_{\mathrm{i}}\right)$ ingested by Acartia tonsa was calculated as:

$$
\% P_{\mathrm{i}}=\frac{\left[\left[P_{\mathrm{o}} \mathrm{e}^{\mu t}-P_{\mathrm{o}}\right]-\left[P_{\mathrm{o}} \mathrm{e}^{(\mu-G) t}-P_{\mathrm{o}}\right]\right]}{\left(P_{\mathrm{o}} \mathrm{e}^{\mu t}-P_{\mathrm{o}}\right)} \times 100
$$

where $t$ is duration of incubation (d), $P_{\mathrm{o}}$ is initial prey density, $\mu$ is daily phytoplankton growth determined from dilution assays (Putland \& Iverson 2007) and $G$ $\left(\mathrm{d}^{-1}\right)$ was calculated as:

$$
G=F_{\text {phyto }}(N)
$$

where $F_{\text {phyto }}$ is clearance rate on phytoplankton (ml adult ${ }^{-1} \mathrm{~d}^{-1}$ ) and $N$ is the in situ abundance of $A$. tonsa (adults $\left.\mathrm{ml}^{-1}\right)$. Per capita ingestion rate $\left(I, \mu \mathrm{g} \mathrm{C}\right.$ adult ${ }^{-1}$ $\mathrm{d}^{-1}$ ) was calculated as:

$$
I=F\left(C_{\mathrm{o}}\right)
$$

where $F$ is clearance rate $\left(\mathrm{ml}\right.$ adult $\left.{ }^{-1} \mathrm{~d}^{-1}\right)$ and $C_{\mathrm{o}}$ is ini-

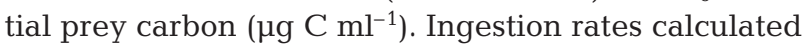
this way are slightly higher than those calculated with the mean prey biomass. However, in our experiments, there was no statistical difference between the rates of ingestion calculated with initial and mean prey biomasses. Per capita total ingestion rate $\left(I_{\text {total }}, \mu \mathrm{g} C\right.$ adult $^{-1} \mathrm{~d}^{-1}$ ) was calculated as:

$$
I_{\text {total }}=I_{\text {phyto }}+I_{\text {mzp }}
$$

where $I_{\text {phyto }}$ and $I_{\text {mzp }}$ represent $A$. tonsa per capita ingestion rates of phytoplankton and microzooplankton, respectively.

Relative Preference Indices (RPI) were calculated for each prey by adapting equations from McCarthy et al. (1977). RPIs were calculated as:

$$
\mathrm{RPI}=\frac{\left(I_{\text {prey }} / I_{\text {total }}\right)}{\left(C_{\text {prey }} / C_{\text {total }}\right)}
$$

where $I_{\text {prey }}$ is the per capita prey carbon ingested; $C_{\text {prey }}$ is prey carbon in situ; $C_{\text {total }}$ is total prey carbon in situ. RPIs $>1$ indicate preference for the prey item, $<1$ indicate avoidance of the prey item, and values of unity indicate that prey are ingested in proportion to their availability in situ.

Conversion factors. Phytoplankton carbon concentration was estimated from chlorophyll concentration and carbon:chlorophyll ratios determined for Apalachicola Bay (J. N. Putland \& R. L. Iverson unpubl. data). The ratios were determined from chlorophyll concentration estimated by fluorometry (Welschmeyer 1994) and phytoplankton carbon concentration. Phytoplankton carbon concentration was estimated from phytoplankton abundances, cell volume (Wetzel \& Likens 1991), and carbon to volume formulae for diatoms and protists other than diatoms (Menden-Deuer \& Lessard 2000). Ratios ranged from 4 to 250, and the average ratio was 60 .

Protist (nanoflagellates, ciliates, dinoflagellates) carbon concentration was estimated from cell abundances, cell volume, and carbon to volume formula for protists other than diatoms (Menden-Deuer \& Lessard 2000). For each sample, about 10 randomly chosen cells were measured and volumes estimated with suitable formulae (Wetzel \& Likens 1991, p. 139-165). Body carbon of adult Acartia tonsa was predicted from prosome length and formulae to convert prosome length to body carbon (Berggreen et al. 1988). 
Egg production rate. A method similar to that of Runge \& Roff (2000) was used to determine the rate of Acartia tonsa egg production. Seawater was collected with a darkened polycarbonate carboy from a depth of about $0.5 \mathrm{~m}$ below sea surface. Upon arrival at the FSU marine laboratory, seawater $(<20 \mu \mathrm{m}$ filtered $)$ was added to 11 polyethylene incubation bottles through silicon tubing that was equipped with $20 \mu \mathrm{m}$ Nitex screening. Three bottles were filled per station. A total of 5 to 20 adult copepods (males plus females) were added to each bottle. To facilitate capture of live copepods, animals were anaesthetized as described earlier. Experiments with adult Acartia tonsa fed Rhodomonas salina demonstrated that the anaesthetic dose and exposure time did not significantly affect egg production rate. All bottles were incubated in an outdoor incubator flushed continually with seawater from Apalachicola Bay. Incident irradiance was attenuated with neutral density screening to simulate the light energy from the collection site.

After an incubation period of about $24 \mathrm{~h}$ during summer and $48 \mathrm{~h}$ during winter, copepods were removed from the bottles by filtering the contents of the bottles through a $202 \mu \mathrm{m}$ Nitex screen. Filtered copepods were washed into a dish of filtered seawater. Copepods that were alive were counted. Animals were preserved in acid Lugol's (10\% final concentration) and counted immediately. Bottles containing the $<202 \mu \mathrm{m}$ filtrate were re-incubated in the outdoor incubator. Nauplii were removed from the bottles after about 24 and $48 \mathrm{~h}$ for summer and winter samples, respectively, by filtering the contents of the bottles through a $20 \mu \mathrm{m}$ Nitex screen. Filtered nauplii were gently washed into a bottle, preserved with acid Lugol's (10\% final volume), and counted immediately. Viable Egg Production Rate (VEPR) was calculated as:

$$
\mathrm{EPR}=\frac{1}{T}\left(\frac{\text { No. nauplii }}{\text { No. females }}\right)
$$

where $T$ is the initial incubation period, Nauplii is the number of nauplii that hatched during the second incubation period, and Females is the number of live adult female Acartia tonsa counted at the end of the first incubation period.

Egg production efficiency. Egg production efficiency (EPE) was calculated for Acartia tonsa. EPR was converted to carbon assuming eggs contained $0.14 \times$ $10^{-6} \mu \mathrm{g} \mathrm{C} \mu \mathrm{m}^{-3}$ (Kiørboe et al. 1985a). Average egg diameter in Apalachicola Bay was $65 \mu \mathrm{m}$. EPE was calculated as:

$$
\mathrm{EPE}=\frac{\mu \mathrm{g} \mathrm{egg} \mathrm{C} \text { female }^{-1} \mathrm{~d}^{-1}}{I_{\text {tot }}}
$$

The C:N ratio of food ingested by Acartia tonsa was also calculated by dividing per capita total carbon ingested by nitrogen ingested. We calculated the nitrogen ingested by assuming gross growth efficiency of nitrogen to be $36 \%$ (Kiørboe 1989) and by converting EPR to nitrogen by assuming $0.007 \mu \mathrm{g} \mathrm{N} \mathrm{egg}^{-1}$ (Ambler 1985).

Products of photosynthesis. To assess the quality of the phytoplankton available, the percentage of fixed carbon allocated to the synthesis of lipid, protein, polysaccharides, and low molecular weight (LMW) compounds was examined across the nutrient/salinity gradient during 2004 (August, September, October, and December) and in February 2005. Seawater was collected with a darkened polycarbonate carboy from about $0.5 \mathrm{~m}$ depth, and transported within $4 \mathrm{~h}$ of collection to the Florida State University Edward Ball Marine Laboratory. For each station, 3 clear $125 \mathrm{ml}$ glass bottles were filled with seawater and then inoculated with $\sim 10 \mu \mathrm{Ci}$ of $\mathrm{NaH}^{14} \mathrm{CO}_{3}$. Preliminary experiments verified that the rate of photosynthesis in glass bottles was not significantly different from that in polycarbonate bottles. Bottles were incubated in an outdoor incubator flushed continually with seawater from Apalachicola Bay. Incident irradiance was attenuated with neutral density screening to simulate the light energy from the collection site. After an incubation period of about $24 \mathrm{~h}$, samples were filtered through $25 \mathrm{~mm} \mathrm{GF} / \mathrm{F}$ filters at $<117 \mathrm{~mm} \mathrm{Hg}$ vacuum. Filtered samples were stored in darkness at $-20^{\circ} \mathrm{C}$ and analyzed within 1 mo of sample collection.

Incorporation of ${ }^{14} \mathrm{C}$ into lipid, protein, polysaccharide, and low molecular weight (LMW) compounds were determined following procedures modified from Li et al. (1980) and Rivkin (1985). Filters were vortex mixed with $3 \mathrm{ml}$ of chloroform and $1.5 \mathrm{ml}$ of a 99:1 mixture of methanol/acetic acid and then stored at $4{ }^{\circ} \mathrm{C}$ for $30 \mathrm{~min}$. The filter was vortex mixed again and rinsed with $1.5 \mathrm{ml}$ of chloroform before being filtered through a $25 \mathrm{~mm}$ GF/F filter at $<117 \mathrm{~mm} \mathrm{Hg}$ vacuum into a connecting tube. Distilled water $(1 \mathrm{ml})$ was added to the filtrate. The filtrate was vortexed and then centrifuged at $4000 \mathrm{rpm}$ for $10 \mathrm{~min}$. Aliquots $(1 \mathrm{ml})$ were sampled from each phase and transferred to a liquid scintillation vial. The aliquot from the chloroform phase was air dried overnight. Liquid scintillation cocktail $(10 \mathrm{ml})$ was added to each vial. The methanol soluble fraction contains low molecular weight metabolites and the chloroform phase contains lipids.

The filter was placed into a glass vial with $3 \mathrm{ml}$ of $5 \%$ trichloroacetic acid (TCA). The suspension was heated in a sand bath to $95^{\circ} \mathrm{C}$ for $45 \mathrm{~min}$. The slurry was then filtered through a $25 \mathrm{~mm} \mathrm{GF/F} \mathrm{filter} \mathrm{at}<117 \mathrm{~mm} \mathrm{Hg}$ vacuum into a connecting tube. The filter was rinsed with $2 \mathrm{ml}$ of ice-chilled $5 \%$ TCA. Filtrate $(1 \mathrm{ml})$ containing polysaccharides was placed into a liquid scintillation vial. The filter containing proteins was placed 
into another liquid scintillation vial. Liquid scintillation cocktail $(10 \mathrm{ml})$ was added to each vial.

Samples were counted with a Wallac liquid scintillation counter. Quench curves for each solvent/treatment were determined and used to calculate disintegrations $\mathrm{min}^{-1}$. Counts for the lipid fraction were multiplied by $4.5 \mathrm{ml}$ to estimate total ${ }^{14} \mathrm{C}$ incorporated into lipid compounds. Likewise, counts for the low molecular weight and polysaccharide fraction were multiplied by $2.5 \mathrm{ml}$ and $5 \mathrm{ml}$, respectively to estimate total ${ }^{14} \mathrm{C}$ incorporated into low molecular weight and polysaccharide compounds. These factors correspond to the total extract volume for the respective fractions.

Statistical analyses. Analysis of covariance tests were used to determine whether significant differences existed between times for relationships between variables. If no significant difference was found, data were pooled and a common regression equation was determined. If significant differences were found, data were not pooled. Relationships were considered significant at $p<0.05$ (Sokal \& Rohlf 1995). Non-linear regressions were used when a linear regression model did not adequately explain the relation between variables (for example, low coefficient of determination, heteroscedastic variance). Non-linear relationships were analyzed by dividing the data into 2 components: (1) the initial increasing segment and (2) the latter decreasing segment. ANCOVA tests were performed on each segment.

\section{RESULTS}

\section{Temperature}

There was no relationship between surface salinity and temperature at any time that we sampled. Average

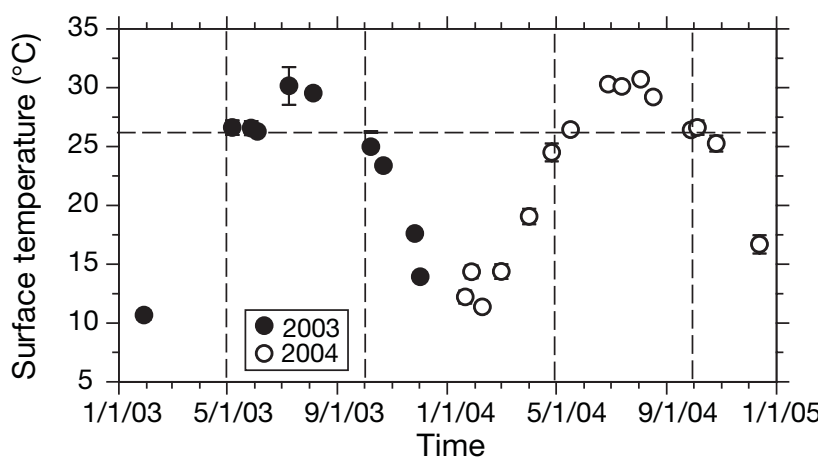

Fig. 2. Annual cycle of surface temperatures (Mean \pm SD) during 2003 and 2004. Summer defined as temperatures above about $26^{\circ} \mathrm{C}$ (horizontal dashed line), which typically corresponds to the time period between about May and October (denoted by vertical dashed lines). Time: mo/d/yr surface temperature in Apalachicola Bay peaked between about May and October during both years. We defined temperatures above about $26^{\circ} \mathrm{C}$ as summer and those below $26^{\circ} \mathrm{C}$ as winter (Fig. 2).

\section{Prey carbon}

Total prey carbon (phytoplankton $>5 \mu \mathrm{m}$ plus microzooplankton $>5 \mu \mathrm{m})$ was highest during summer (Fig. 3A). During summer, total prey carbon was
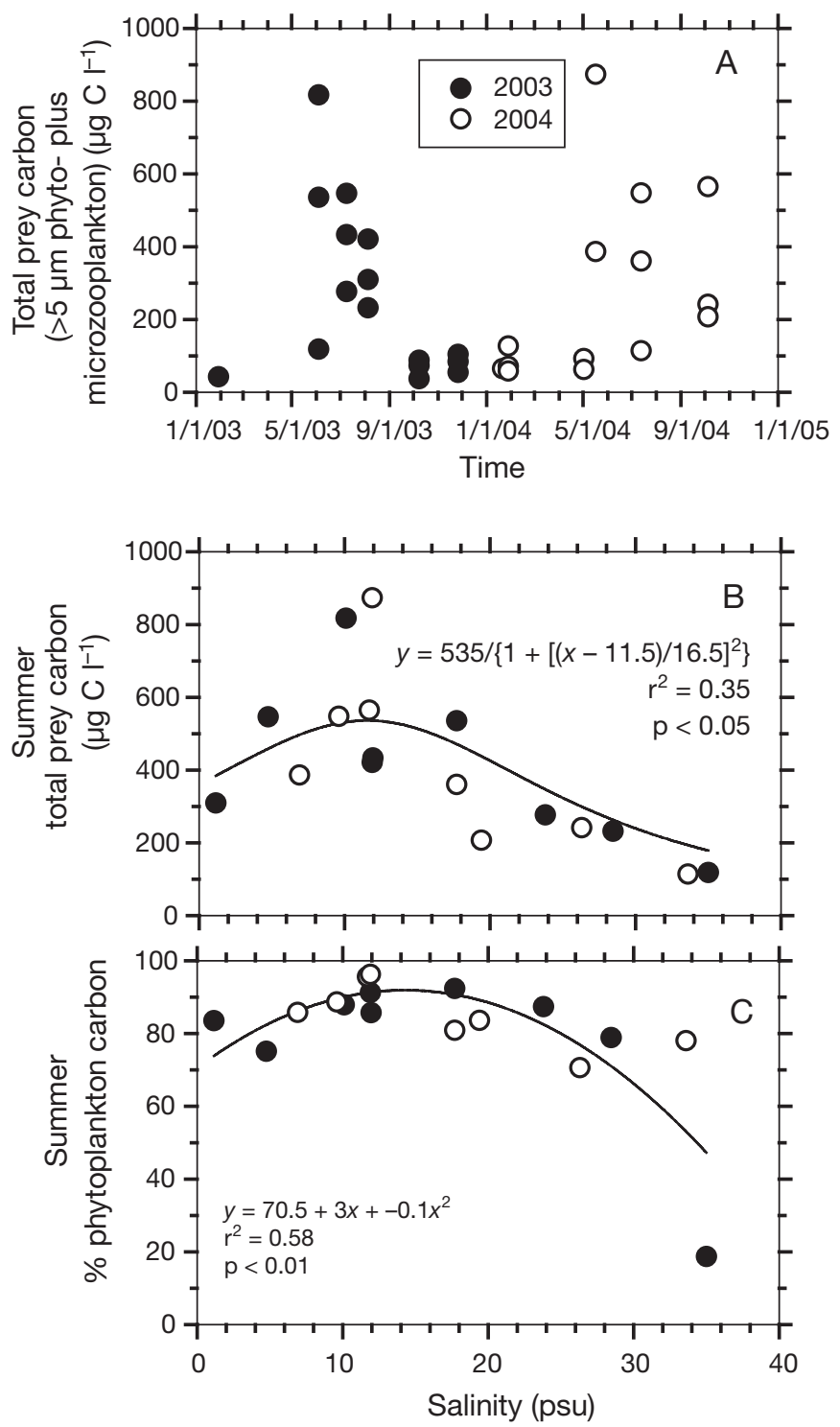

Fig. 3. (A) Annual cycle of total Acartia tonsa prey carbon (phytoplankton $>5 \mu \mathrm{m}$ plus microzooplankton $>5 \mu \mathrm{m}$ ). (B) Summer total prey carbon with respect to surface salinity. (C) Summer percent of total prey carbon composed of phytoplankton carbon $>5 \mu \mathrm{m}$ with respect to surface salinity. Regression equations are shown 
related to salinity, peaking between about 6 and 16 psu (Fig. 3B). At salinities below 32 psu, total prey carbon during summer was primarily composed of phytoplankton $>5 \mu \mathrm{m}$ (Fig. $3 \mathrm{C}$ ).

\section{Acartia tonsa abundance}

Abundance averaged $2 \pm 1(\mathrm{SD}) \mathrm{l}^{-1}$ and $0.6 \pm 0.6 \mathrm{l}^{-1}$ during winter and summer 2003, respectively. In contrast, abundance averaged $0.6 \pm 0.9 \mathrm{l}^{-1}$ and $3.3 \pm$ $3.7 \mathrm{l}^{-1}$ during winter and summer 2004, respectively (Fig 4A). There was no significant relationship between abundance and salinity during summer 2003. We compared our summer 2004 data, when average river discharge rates into the Apalachicola Bay were about $400 \mathrm{~m}^{3} \mathrm{~s}^{-1}$, to abundance data collected by Edmiston (1979) and Marcus (1991), when river discharge into the bay was similar (Fig. 4B). Together these data sets suggest that during summer, when average discharge is about $400 \mathrm{~m}^{3} \mathrm{~s}^{-1}$, abundance of adult $A$. tonsa peaks at about $12 \mathrm{l}^{-1}$ between $\sim 14$ and 22 psu.
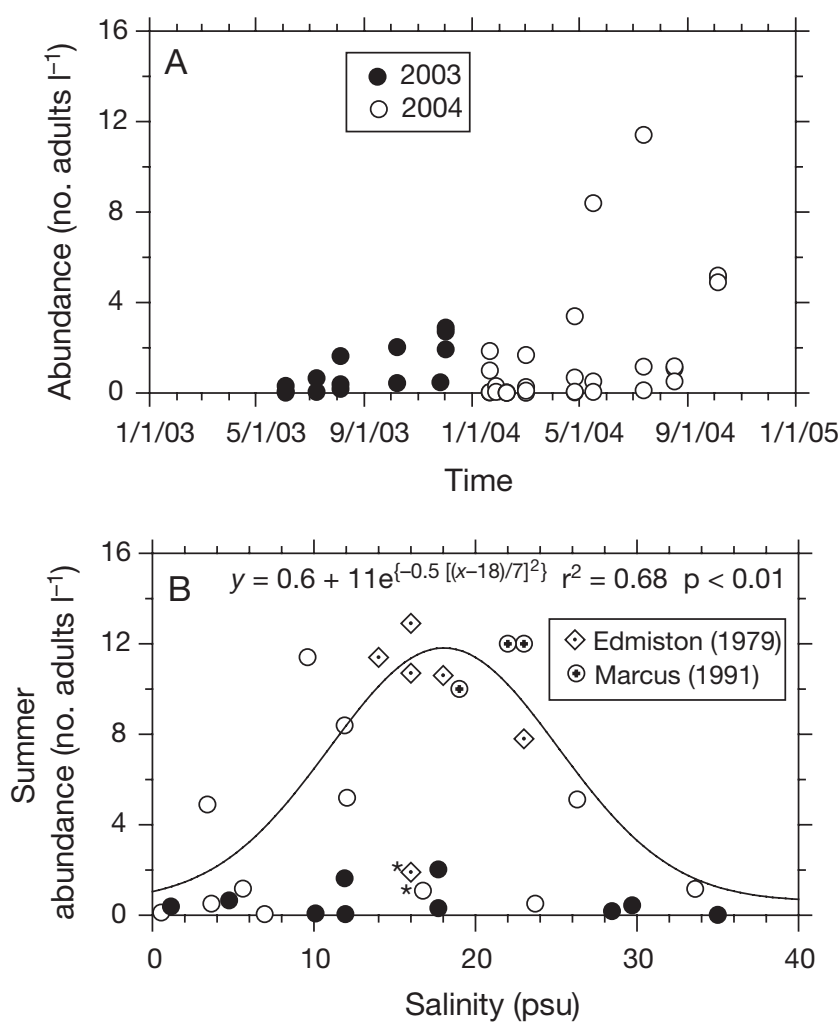

Fig. 4. Acartia tonsa. (A) Abundance of adult copepods throughout 2003 and 2004. (B) Summer abundance of adults with respect to sea surface salinity. Data with asterisks were not included in regression. Data sources are shown. Time: $\mathrm{mo} / \mathrm{d} / \mathrm{yr}$

\section{Acartia tonsa grazing}

Despite application of the general method of Njestgaard et al. (2001) to correct rates of herbivory, adult Acartia tonsa did not ingest enough phytoplankton to appreciably affect phytoplankton growth on any of the 22 dates when we estimated herbivory. The average $\% P_{\mathrm{i}}$ was $2.2 \pm 5.3(\mathrm{SD}) \%$ (median $0.4 \%$ ). The $\% P_{\mathrm{i}}$ did not show any seasonal trend (Fig. 5A) or relationship with salinity (Fig. 5B). Clearance rates on phytoplankton peaked at about $100 \mu \mathrm{g} \mathrm{Cl}^{-1}$ of phytoplankton $>5 \mu \mathrm{m}$ in size and ranged from 0 to $45 \mathrm{ml}_{\text {Adult }}{ }^{-1} \mathrm{~d}^{-1}$ (Fig. 6).

On average, the adult specimens of Acartia tonsa in the incubation bottles ingested $9 \pm 9$ (SD) \% of the total food stock available. Per capita total ingestion rates were highest during summer (Fig. 7A). Average ingestion was $1.1 \pm 1.3(\mathrm{SD}) \mu \mathrm{g} \mathrm{C}$ Adult ${ }^{-1} \mathrm{~d}^{-1}$ and $2.2 \pm 1.8 \mu \mathrm{g}$ C Adult ${ }^{-1} \mathrm{~d}^{-1}$ during winter and summer, respectively. During summer, per capita total ingestion rate increased below 20 psu (Fig. 7B).

The amount of carbon ingested relative to predicted body carbon tended to be highest during summer (Fig. 7C). On average, A. tonsa ingested the
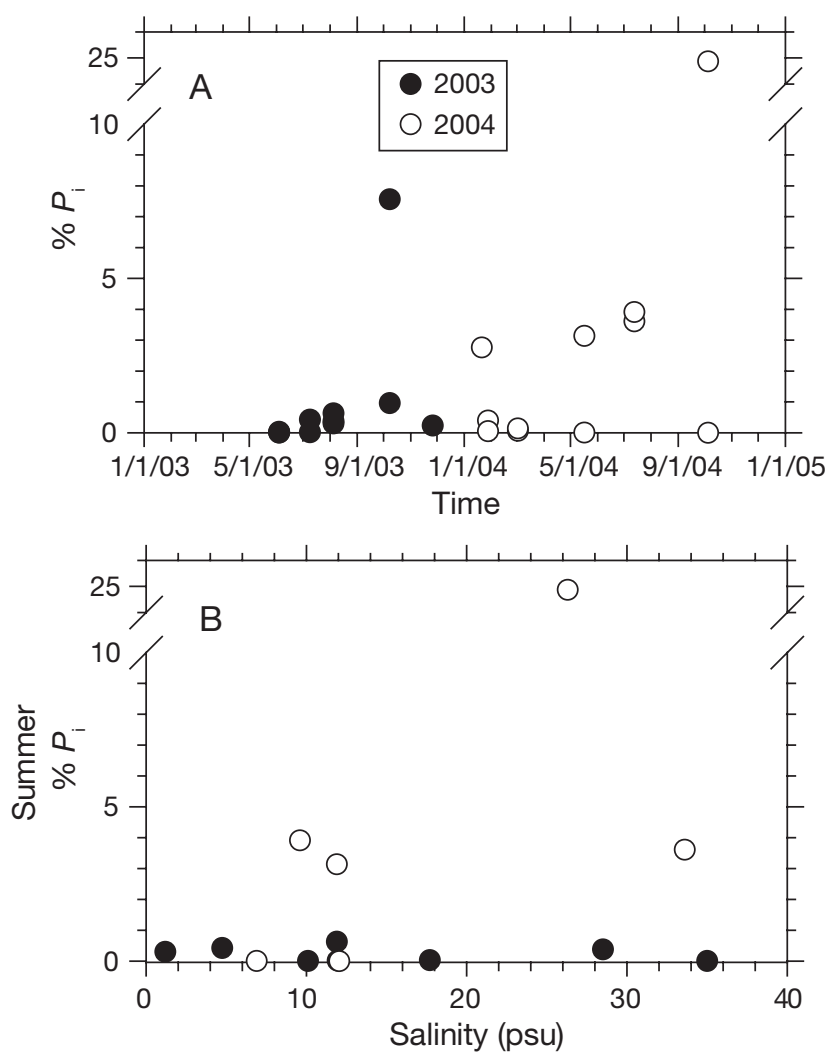

Fig. 5. Acartia tonsa. (A) Percent of phytoplankton productivity $\left(\% P_{\mathrm{i}}\right)$ ingested by adult copepods throughout 2003 and 2004. (B) Percent $P_{\mathrm{i}}$ ingested by adult copepods with respect to surface salinity during summer. Time: $\mathrm{mo} / \mathrm{d} / \mathrm{yr}$ 


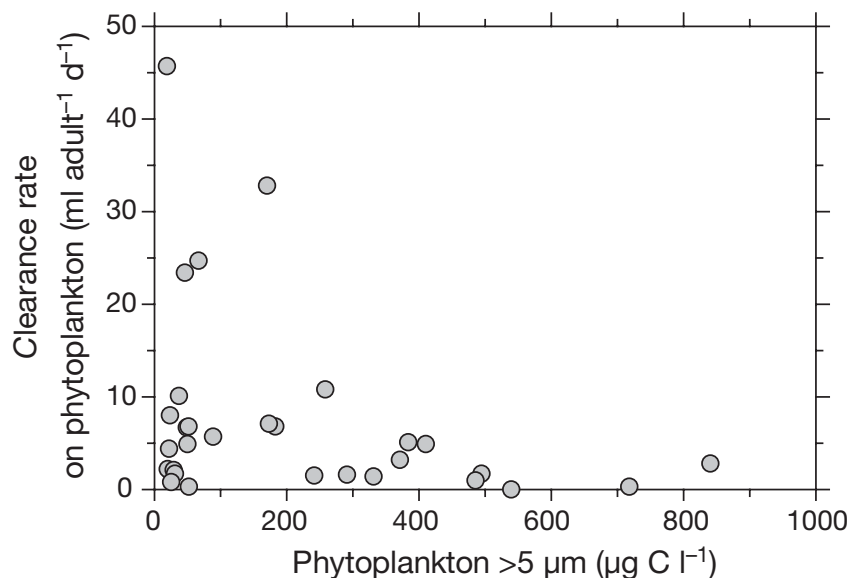

Fig. 6. Acartia tonsa. Feeding response on phytoplankton

equivalent of $38 \pm 48(\mathrm{SD}) \%$ and $120 \pm 93 \%$ body carbon during winter and summer, respectively. Body carbon averaged $2.0 \pm 0.9(\mathrm{SD}, \mathrm{n}=108)$ and $2.3 \pm 0.9$ (n = 152) $\mu \mathrm{g} \mathrm{C}$ Adult $^{-1}$ during 2003 and 2004, respectively. During summer, the amount of carbon in- gested, relative to predicted body carbon, increased below 20 psu (Fig. 7D).

There was no seasonal trend for the percent of diet composed of phytoplankton. There was also no relationship between the percent of diet composed of phytoplankton and salinity. On average, phytoplankton represented $48 \pm 28(\mathrm{SD}) \%$ and $57 \pm 32 \%$ of the diet of adult Acartia tonsa during winter and summer, respectively.

There was no seasonal trend for Relative Preference Indices (RPI) and RPIs were not related to salinity. The RPI for phytoplankton averaged $0.8 \pm 0.4(\mathrm{SD})$ and 0.7 \pm 0.4 during winter and summer, respectively. RPI for microzooplankton averaged $1.2 \pm 0.5$ and $3.9 \pm 5.3$ during winter and summer, respectively.

\section{Egg production rate and efficiency}

The highest rates of egg production (EPR) occurred during summer (Fig. 8A). Average EPRs were $13 \pm$ 15 (SD) eggs female ${ }^{-1} \mathrm{~d}^{-1}$ and $28 \pm 24$ eggs female $^{-1}$ $\mathrm{d}^{-1}$, during winter and summer, respectively. During
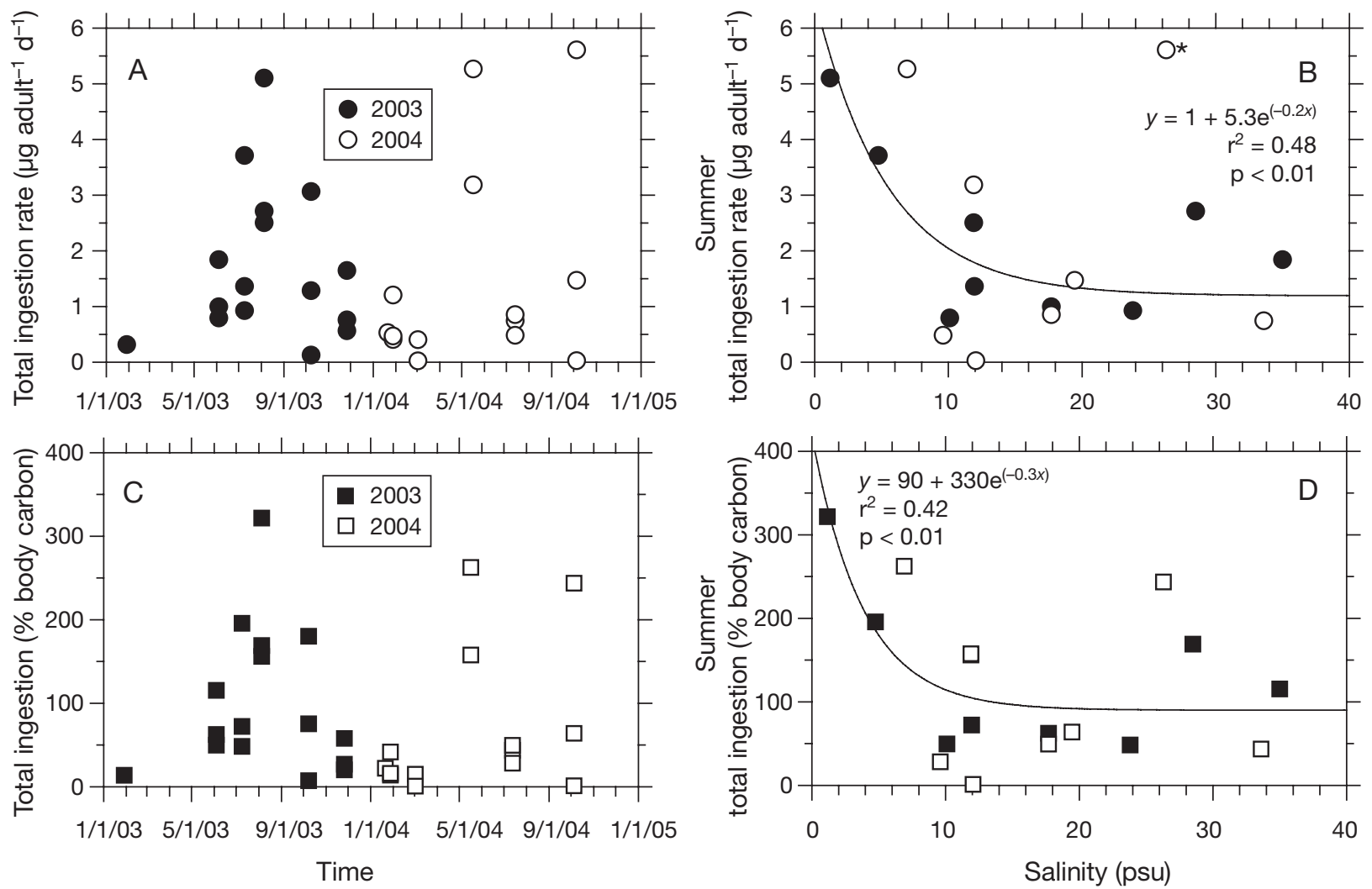

Fig. 7. Acartia tonsa. (A) Annual cycle of per capita total ingestion rate. (B) Summer per capita total ingestion rate relative to surface salinity. Data point with asterisk was not included in regression. (C) Annual cycle of per capita total ingestion, as percent of body carbon. (D) Summer per capita total ingestion, as percent of body carbon, relative to surface salinity. Time: mo/d/yr 

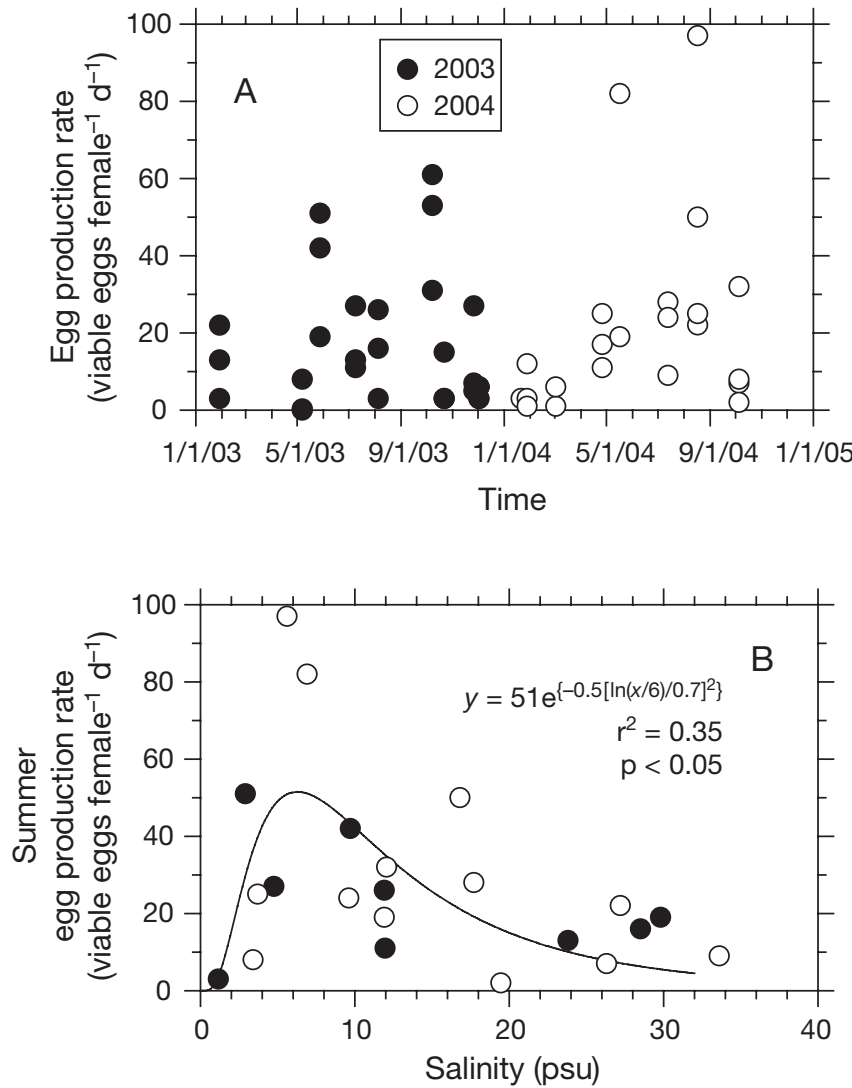

Fig. 8. Acartia tonsa. (A) Annual cycle of egg production rate. (B) Summer egg production rate with respect to surface salinity

summer, EPR was highest between about 4 and 10 psu (Fig. 8B).

Apart from 4 data points between 10 and 12 psu, EPE peaked ( 99\%) between 8 and 14 psu during summer and winter (Fig. 9). In all 3 summer samples that are circled in Fig. 9, >50\% of the abundance of phytoplankton cells $>20 \mu \mathrm{m}$ in size were Thalassiosira spp. Phytoplankton were not counted in the winter sample that is denoted with an asterisk in Fig. 9; therefore, we do not know whether Thalassiosira spp. formed a large percent of the algal community. There were 3 data points that had EPE values $>100 \%$. Two of the data points were from winter and had EPE values of $725 \%$ and $390 \%$. One of the data points was from summer and had an EPE value of $2424 \%$. These high values occurred at about 11, 12, and 23 psu and were considered erroneous and removed from the data set.

Between 5 and 20 psu, the average C:N mass ratio of food ingested was $6 \pm 13$ (SD) (Fig. 9). In higher salinity (>20 psu) water, the C:N mass ratio of food ingested was $12 \pm 11$. In lower salinity $(<5 \mathrm{psu})$ water, the C:N mass ratio of food ingested was $48 \pm 57$.

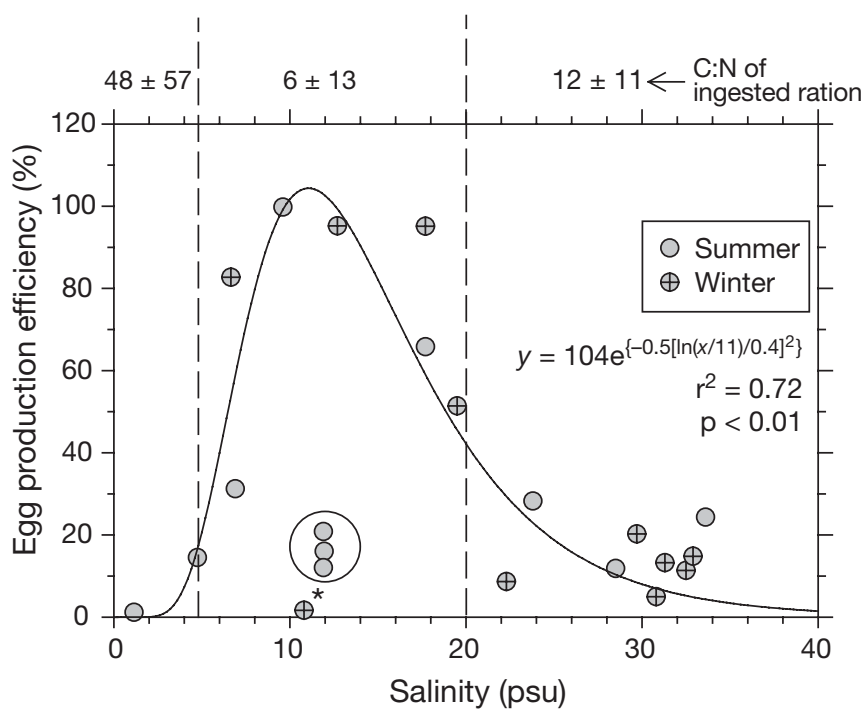

Fig. 9. Acartia tonsa. Egg production efficiency during winter and summer with respect to surface salinity. Also shown is the calculated $\mathrm{C}: \mathrm{N}$ mass ratio $( \pm \mathrm{SD})$ of ingested ration below 5 psu, between 5 and 20 psu, and above 20 psu. Symbol with asterisk and circled symbols denote samples not included in regression. The circled symbols denote samples that had a high percent of Thalassiosira spp. present in the phytoplankton community

\section{Products of photosynthesis}

The method that was used to estimate the fraction of carbon productivity allocated to the synthesis of protein, lipid, and carbohydrate did not lead to a calculated loss of fixed carbon. On average, total radioactivity from split samples was $103 \pm 20$ (SD)\% of total radioactivity from un-split samples. Of total carbon fixed, $<20 \%$ was allocated toward the synthesis of low molecular weight compounds. The percentages of carbon allocated toward the synthesis of protein and lipid compounds were inversely related to salinity (Fig. $10 \mathrm{~A}, \mathrm{~B})$. In contrast, the percent of carbon allocated toward the synthesis of polysaccharide compounds was positively related to salinity (Fig. 10C).

\section{DISCUSSION}

\section{Ingestion of phytoplankton and microzooplankton}

Acartia tonsa is omnivorous in estuarine waters (Table 2). In Apalachicola Bay, Acartia tonsa had a mixed diet consisting of phytoplankton and microzooplankton. On average, phytoplankton contributed $53 \pm$ $30( \pm 1 \mathrm{SD}) \%$ to the diet of $A$. tonsa. The average relative preference index (RPI) for phytoplankton was about 1 , indicating that phytoplankton were ingested 


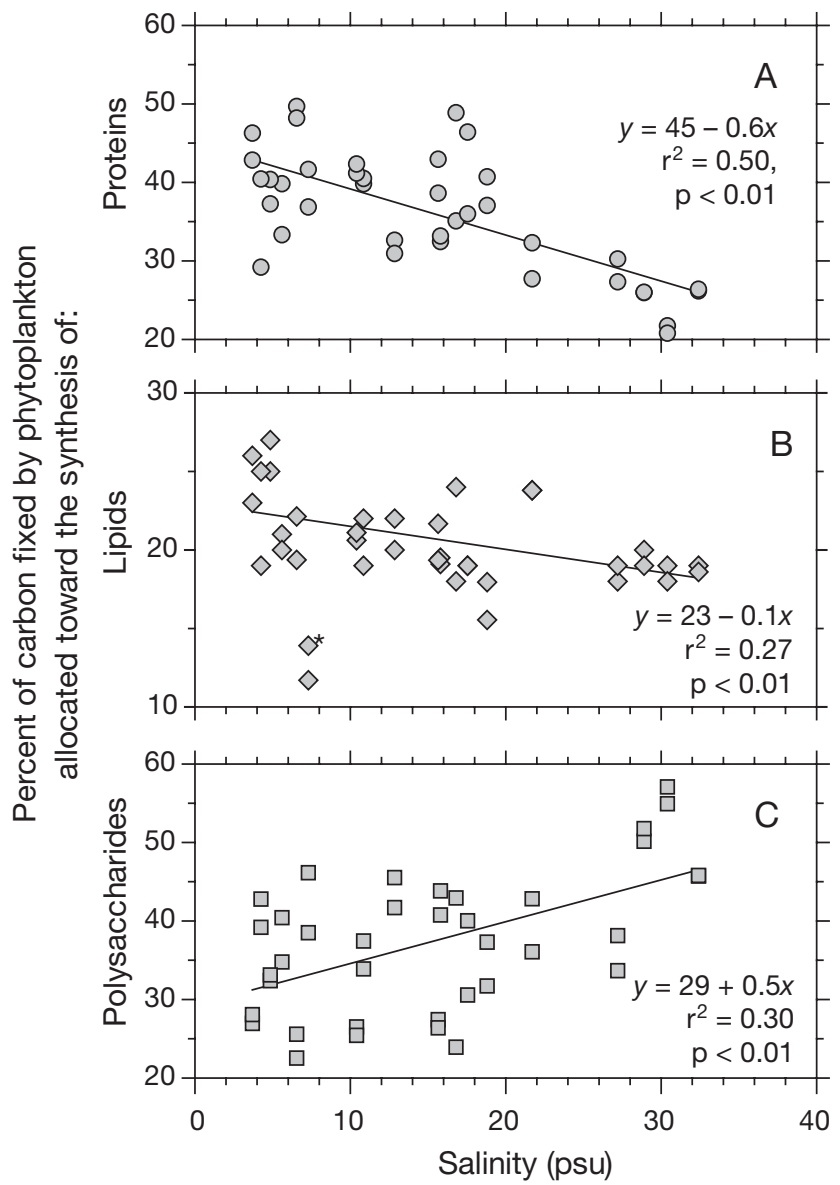

Fig. 10. (A) Percent of total carbon fixed allocated toward protein synthesis with respect to surface salinity. (B) Percent of total carbon fixed allocated toward lipid synthesis with respect to surface salinity. Asterisk denotes data not included in regression. (C) Percent of total carbon fixed allocated toward polysaccharide synthesis with respect to surface salinity in proportion to their availability in situ. In contrast, the average RPI for microzooplankton was $>1$, indicating that the proportion of microzooplankton carbon in $A$. tonsa's diet was greater than that occurring in situ. Relatively high RPI for microzooplankton is generally the result of higher clearance rates on microzooplankton than on phytoplankton (Stoecker \& Egloff 1987). Relatively high clearance rates on microzooplankton may be related to microzooplankton motility, size and quality. Unlike non-motile species, motile prey such as microzooplankton have increased encounter rates with A. tonsa. In addition, motile prey should be more easily detected by predators because their swimming generates a hydrodynamic signal detectable by $A$. tonsa (Jonsson \& Tiselius 1990). In Apalachicola Bay, a large portion of the phytoplankton biomass is $<5 \mu \mathrm{m}$ ( J. N. Putland \& R. L. Iverson unpubl. data) and therefore inaccessible to adult A. tonsa (Berggreen et al. 1988). Microzooplankton may be a more optimal size for capture and retention (Berggreen et al. 1988, Jonsson \& Tiselius 1990). A. tonsa may also preferentially ingest microzooplankton to meet their nutritional dietary requirements (Kleppel 1993, Jones \& Flynn 2005, Tang $\&$ Taal 2005).

This is the first study to document the seasonal and salinity related patterns of per capita total ingestion rates of Acartia tonsa in an estuary. Per capita total ingestion rates peaked during summer (Fig. 7A) below about 20 psu (Fig. 7B). Combining data from various estuaries also suggests that per capita total ingestion rates of Acartia spp. peak during summer (Fig. 11). The temporal pattern of ingestion seen in Apalachicola Bay and other estuaries is most likely related to the annual cycle of temperature and prey biomass. The peak ingestion rate that was observed in lower salinity

Table 2. Summary of estuarine field experiments on mesozooplankton grazing. Group is the mesozooplankton group examined. Time is the season when experiments were conducted ( $\mathrm{S}$ - spring, $\mathrm{Su}$ - summer, F-fall, W - winter). EPR is egg production rate (eggs female $\mathrm{e}^{-1} \mathrm{~d}^{-1}$ ). \% Diet is the percent of total carbon ingested composed of microzooplankton. IR is the per capita total ingestion rate $\left(\mu \mathrm{g} \mathrm{C}\right.$ adult $\left.{ }^{-1} \mathrm{~d}^{-1}\right) . \% P_{\mathrm{i}}$ is the percent of phytoplankton productivity ingested. nd: not determined. dnr: did not report. Mesozooplk. = mesozooplankton

\begin{tabular}{|lllccccl|}
\hline Group & Estuary & Time & EPR & \% Diet & IR & $\%^{2} \mathrm{P}_{\mathrm{i}}$ & Source \\
\hline Acartia tonsa & Terrebonne & $\mathrm{Su} / \mathrm{F} / \mathrm{W}$ & nd & $3-41$ & $3-6$ & nd & Gifford \& Dagg (1988) \\
Acartia tonsa & Chesapeake & $\mathrm{S} / \mathrm{Su}$ & $21-75$ & $13-80$ & $1-3$ & nd & White \& Roman (1992) \\
Acartia tonsa & Los Angeles & $\mathrm{S} / \mathrm{Su} / \mathrm{F} / \mathrm{W}$ & $3-23$ & $0-95$ & $0-2$ & nd & Kleppel (1992) \\
Acartia tonsa & Fourleague & $\mathrm{S} / \mathrm{Su} / \mathrm{F} / \mathrm{W}$ & nd & nd & nd & $1-3$ & Dagg (1995a) \\
Acartia tonsa & Florida & $\mathrm{S} / \mathrm{Su} / \mathrm{F} / \mathrm{W}$ & $1-16$ & $\mathrm{dnr}$ & $0-10$ & nd & Kleppel \& Hazzard (2000) \\
Acartia spp. & San Francisco & $\mathrm{S}$ & nd & $0-91$ & $0-5$ & nd & Rollwagen Bollens \& Penry (2003) \\
Acartia tonsa & Apalachicola & $\mathrm{S} / \mathrm{Su} / \mathrm{F} / \mathrm{W}$ & $0-100$ & $0-100$ & $0-6$ & $0-24$ & Present study \\
Copepods & Mississippi & $\mathrm{S} / \mathrm{Su}$ & nd & nd & nd & $4-62$ & Dagg (1995b) \\
Mesozooplk. & Gironde & $\mathrm{S}$ & nd & nd & nd & $9-40$ & Sautour et al. (2000) \\
Mesozooplk. & Kariega & $\mathrm{S} / \mathrm{Su} / \mathrm{F} / \mathrm{W}$ & nd & nd & nd & $1-58$ & Froneman (2001) \\
Mesozooplk. & Kasouga & $\mathrm{S} / \mathrm{Su} / \mathrm{F} / \mathrm{W}$ & nd & nd & nd & $0-46$ & Froneman (2004) \\
Mesozooplk. & Mississippi & $\mathrm{S}$ & nd & $1-40$ & nd & nd & Liu et al. (2005) \\
\hline
\end{tabular}




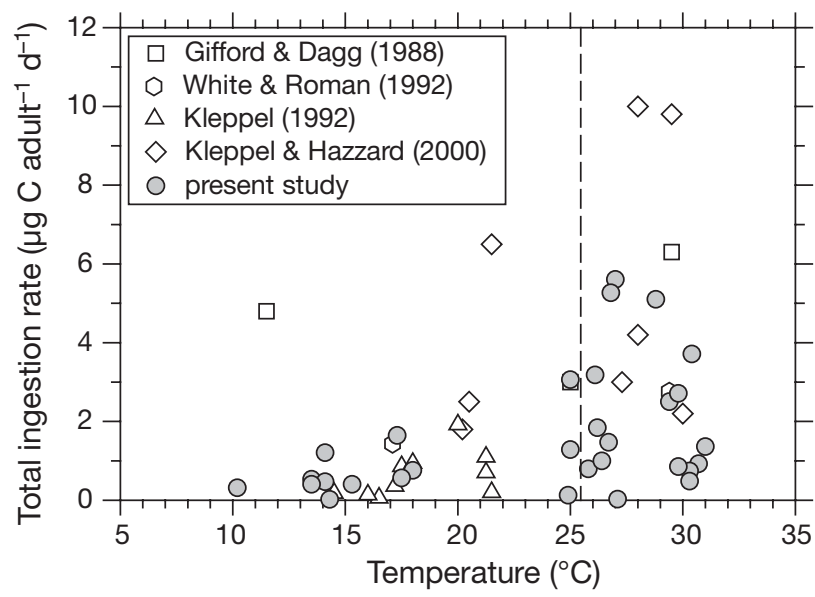

Fig. 11. Acartia tonsa. Per capita total ingestion rate with respect to surface temperature. Vertical dashed line demarcates winter from summer. Data sources are shown

waters in Apalachicola Bay was probably the result of the peak in prey biomass as there was no spatial variation in surface temperature in the bay.

\section{Egg production rate}

Our estimates of Acartia tonsa egg production in Apalachicola Bay are within the same range as those reported in other subtropical estuaries (Table 2). Peak egg production rates during summer are thought to result from higher temperatures (Ambler 1985, White \& Roman 1992) and higher ingestion rates (Kiørboe et al. 1985b, Kleppel 1992). Likewise, EPR in Apalachicola Bay were highest during summer (Fig. 8A) when temperature, ingestion rate, and ingested ration as \% of body carbon were highest (Figs. 2 \& 7).

Ambler et al. (1985) observed that EPR near Galveston Bay was greatest in lower salinity water. Similarly, in Apalachicola Bay EPR was highest in lower salinity waters (4 and 10 psu) during summer (Fig. 8B). The pattern in EPR with respect to salinity is probably related to ingestion rate (Fig. 7B) and EPE (Fig. 9) as ingestion rates increased below 20 psu and EPE was highest between about 8 and 14 psu.

The relationships between Acartia tonsa total ingestion, EPR, EPE and salinity observed in Apalachicola Bay have not been reported in other estuaries. In fact, few studies have simultaneously examined $A$. tonsa total ingestion and EPR in an estuary (Table 2). To our knowledge, only 1 other study (Kleppel \& Hazzard 2000) simultaneously examined total ingestion and EPR at different locations in an estuary; however, in that study (op. cit.), only 2 stations were sampled. At the stations in Florida Bay examined by Kleppel \&
Hazzard (2000) during summer, salinity was typically above 25 psu. Compared to our estimates of ingestion rate, EPR, and EPE above 25 psu during summer, their estimates of ingestion rate were higher, estimates of EPR were about the same, and estimates of EPE were lower. On 3 of the 4 dates examined during summer, ingestion rates measured by Kleppel \& Hazzard (2000) were greater than those predicted. This may explain why estimates of EPE in higher salinity waters were low compared to EPE estimated in Apalachicola Bay during summer in higher salinity waters.

\section{Egg production efficiency}

While the average EPE $(\sim 33 \%)$ was similar to the average gross growth efficiency $(\sim 30 \%)$ of planktonic crustaceans in the laboratory (Straile 1997), the EPE ranged from 1 to $99 \%$. The high values of EPE estimated in this study could be related in part to the fact that we did not estimate the ingestion of eggs, nauplii, or detritus. However, the fact that peak EPE occurred near the optimal salinity (15 to $22 \mathrm{psu}$ ) for Acartia tonsa (Cervetto et al. 1999) suggests that the pattern in EPE is related to salinity tolerance. Peak EPE in lower salinity waters could be the result of optimal enzyme activity and/or reduced energy to maintain osmotic balance (Mauchline 1998). However, EPE may also depend on food quality (Kiørboe 1989) as the peak EPE was similar to EPE when $A$. tonsa are fed optimal quality prey in the laboratory (Tang \& Taal 2005).

The efficiency with which ingested carbon is converted into zooplankton biomass in the laboratory is influenced by food quality. Foods high in protein (Kiørboe 1989, Kleppel et al. 1998) and/or lipid (Broglio et al. 2003, Tang \& Taal 2005) generally lead to high EPE and EPR. In Apalachicola Bay, phytoplankton carbon was a large fraction of the diet of Acartia tonsa. There are several lines of evidence to suggest that phytoplankton were relatively rich in protein and lipid in lower salinity waters of Apalachicola Bay, where maximum EPE occurred, compared to higher salinity waters.

Phytoplankton that are nitrogen replete have more protein and lipid than nitrogen deficient phytoplankton (Kiørboe 1989, Klein Breteler et al. 2005). Typically, phytoplankton do not respond to nitrogen enrichment in lower salinity waters of Apalachicola Bay (Fulmer 1997), suggesting they are nitrogen replete and therefore protein and lipid rich. Measurements of the relative production of proteins, lipids, and carbohydrates with ${ }^{14} \mathrm{C}$ incubation and biochemical fractionation procedures indicated that phytoplankton allocated more carbon to protein and lipid synthesis and less to polysaccharide synthesis in lower salinity waters 
of Apalachicola Bay (Fig. 10). In waters where EPE peaked, calculated $\mathrm{C}: \mathrm{N}$ ratios of the ration ingested by Acartia tonsa were close to the Redfield Ratio (Fig. 9) suggesting that food ingested was nitrogen rich, and therefore protein rich.

During summer in Apalachicola Bay, phytoplankton growth is low (J. N. Putland, R. L. Iverson unpubl. data) and nitrogen limited (Fulmer 1997) in nitrogen depleted higher salinity (>30 psu) waters. Under natural conditions, EPR and EPE of Acartia tonsa are low in higher salinity waters (Figs. 8B \& 9). However, when collected from high ( 30 psu) salinity waters near Apalachicola Bay during summer and fed a diet of mixed dinoflagellates that were grown under nutrient replete conditions, A. tonsa attained an EPR of between 60 and 110 eggs female ${ }^{-1} \mathrm{~d}^{-1}$ (Marcus et al. 2004). This EPR is similar to that in lower salinity water and about 10 times greater than the EPR which occurs naturally in higher salinity water (Fig. 8B). Jones \& Flynn (2005) found that EPE increased when A. tonsa were fed a mixed diet of diatoms and dinoflagellates that were grown under nitrogen replete conditions. Therefore, the relatively high EPR reported by Marcus et al. (2004) was probably a response to increased EPE from improved food quality, owing to the mixed dinoflagellate diet that was grown under nutrient replete conditions, as well as increased ingestion rate.

While phytoplankton generally appear to be relatively rich in protein and lipid in lower salinity waters of Apalachicola Bay, there may be times when they are of low quality in lower salinity waters. In the 3 samples from summer, circled in Fig. 9, Thalassiosira spp. constituted a high proportion of the abundance of phytoplankton $>20 \mu \mathrm{m}$ in size. Some species of Thalassiosira can produce anti-proliferative compounds (Miralto et al. 1999) and this may explain the reduced EPE observed at about 12 psu.

We conclude that phytoplankton biochemical composition influenced Acartia tonsa EPE across the salinity gradient in Apalachicola Bay. However, because phytoplankton biochemical composition is correlated with salinity (Fig. 10), it was beyond the scope of the present study to separate the effects of salinity from the effects of phytoplankton biochemical 'quality' in controlling A. tonsa EPE.

\section{Role in estuarine food web}

Herbivory is the product of grazer clearance rate on phytoplankton and grazer abundance. Clearance rates estimated from the particle removal experiments (Fig. 6) were within the same range as those previously reported for Acartia tonsa feeding on phytoplankton (Berggreen et al. 1988, Gifford \& Dagg 1988, Fro- neman 2001). Furthermore, the functional feeding response curve (Fig. 6) is similar to the theoretical functional response curve for zooplankton feeding kinetics (Miller 2004). Patchiness (Wiebe 1972), filtration efficiency (Smith et al. 1968) and splitting of samples (Postel et al. 2000) are some of the most important sources of error associated with estimates of copepod abundance. To address error associated with patchiness, we increased the distance that the net was towed to improve precision (Wiebe 1972). However, this led to sub-optimal filtration efficiencies. Smith et al. (1968) suggested a filtration efficiency of $>85 \%$. The average filtration efficiency for our samples was $67 \pm 17$ (SD) $\%$. Our estimates of Acartia tonsa abundance (Fig. 4), however, are within the same range as previously reported for Apalachicola Bay (Edmiston 1979, Marcus 1991).

We estimated that the percentage of phytoplankton production ingested by adult Acartia tonsa ranged from 0 to $24 \%$, with a median value of $0.4 \%$ (Fig. 5). The grazing impact of adult $A$. tonsa on phytoplankton in Apalachicola Bay was similar to that found for adult copepods and mesozooplankton in other estuaries (Table 2). When compared to the percentage of phytoplankton productivity ingested by microzooplankton (>75\%) (Putland \& Iverson 2007), it is clear that adult A. tonsa were not the primary herbivores in Apalachicola Bay. That A. tonsa had a mixed diet and was not the primary herbivore in this productive estuary supports the concept that a microbial food web best represents mass and energy flow through the planktonic food web in Apalachicola Bay and other estuaries (Putland \& Iverson 2007).

Although Acartia tonsa is not the main planktonic herbivore in Apalachicola Bay, the species is an important prey for higher trophic levels. Like other Gulf of Mexico estuaries, Anchoa mitchilli is the most abundant fish, is present all year in Apalachicola Bay, and supports higher trophic levels such as seatrout, flounder, and redfish (Sheridan 1978). Stomach content analyses indicate that calanoid copepods, principally A. tonsa, are the main prey of adult $A$. mitchilli (Sheridan 1978). In Apalachicola Bay, abundances of $A$. tonsa tend to be highest between 14 to 22 psu (Fig. 4B) while their egg production is highest between 4 to $10 \mathrm{psu}$ (Fig. 8B) and abundances of A. mitchilli are highest between 8 to 14 psu (Fig. 12). This suggests that $A$. tonsa is particularly important food for $A$. mitchilli in lower salinity waters.

\section{Management implications}

The areal extent of lower $(<20$ psu) salinity water decreases in Apalachicola Bay during periods when 


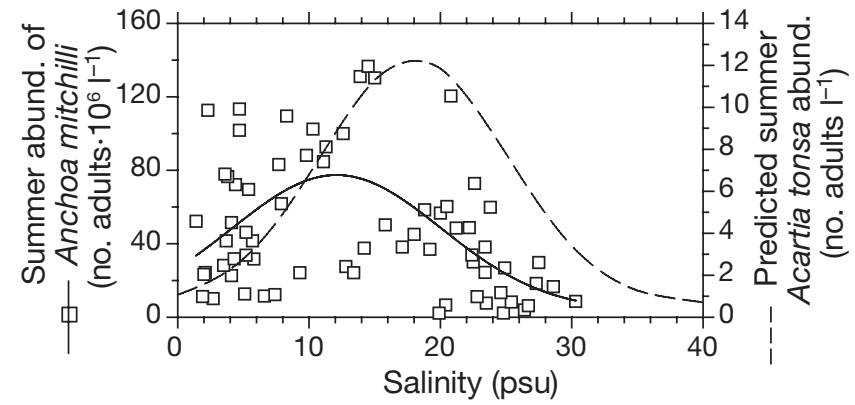

Fig. 12. Anchoa mitchilli and Acartia tonsa. Summer abundance (abund.) of adult $A$. mitchilli with respect to surface salinity. Data courtesy of the Apalachicola Bay National Estuarine Research Reserve. $y=4+74 \mathrm{e}^{\left\{-0.5[(x-12) / 8]^{2}\right\}}, \mathrm{r}^{2}=0.27$, $\mathrm{p}<0.01$. Dashed line is predicted abundance of adult $A$. tonsa from Fig. 4.

river discharge is low (Mortazavi et al. 2001). Therefore, upstream water diversion during summer will decrease the areal extent of lower salinity water where peak ingestion, egg production efficiency, and egg production of Acartia tonsa occur and where A. tonsa are important prey for Anchoa mitchilli. We predict that upstream water diversion during summer will lead to reduced production of fish that are directly (for example, A. tonsa $\rightarrow$ A. mitchilli) or indirectly (for example, A. tonsa $\rightarrow$ A. mitchilli $\rightarrow$ Cynoscion arenarius) nourished by A. tonsa.

Acknowledgements. This research was conducted with a Graduate Research Fellowship award to J.N.P. from the Estuarine Reserves Division, Office of Ocean and Coastal Resource Management, National Ocean Service, National Oceanic and Atmospheric Administration and SRAD funds from the Dept. Oceanography, FSU to R.L.I. The authors thank the Dept. Statistics, FSU for providing statistical consultation, Dept. Biology, FSU for use of their epifluorescence microscope, L. Edmiston at the Apalachicola Bay National Research Reserve for providing assistance with sampling, and G. Lewis, N. Marcus and 3 anonymous reviewers for their constructive comments. This paper is part of a dissertation submitted to the Dept. Oceanography, FSU by J.N.P. in partial fulfillment of a PhD degree. This is Contribution No.1107 of the Florida State University Marine Laboratory.

\section{LITERATURE CITED}

Ambler JW (1985) Seasonal factors affecting egg production and viability of eggs of Acartia tonsa Dana from East Lagoon, Galveston, Texas. Estuar Coast Shelf Sci 20:742-760

Berggreen U, Hansen B, Kiørboe T (1988) Food size spectra, ingestion and growth of the copepod Acartia tonsa during development: implications for determination of copepod production. Mar Biol 99:341-352

Broglio E, Jónasdóttir SH, Calbet A, Jakobsen HH, Saiz E (2003) Effect of heterotrophic versus autotrophic food on feeding and reproduction of the calanoid copepod Acartia tonsa: relationship with prey fatty acid composition. Aquat Microb Ecol 31:267-278
Calbet A (2001) Mesozooplankton grazing effect on primary production: a global comparative analysis in marine systems. Limnol Oceanogr 46:1824-1830

Calbet A, Landry MR (2004) Phytoplankton growth, microzooplankton grazing, and carbon cycling in marine systems. Limnol Oceanogr 49:51-57

Cervetto G, Gaudy R, Pagano M (1999) Influence of salinity on the distribution of Acartia tonsa (Copepod, Calanoida). J Exp Mar Biol Ecol 239:33-45

Chanton J, Lewis FG (2002) Examination of coupling between primary and secondary production in a river-dominated estuary: Apalachicola Bay, Florida, USA. Limnol Oceanogr 47:683-697

Dagg MJ (1995a) Ingestion of phytoplankton by the microzooplankton and mesozooplankton communities in a productive subtropical estuary. J Plankton Res 17:845-857

Dagg M (1995b) Copepod grazing and the fate of phytoplankton in the northern Gulf of Mexico. Cont Shelf Res 15: $1303-1317$

Edmiston HL (1979) The zooplankton of the Apalachicola Bay system. MS thesis, Florida State University, FL

Froneman P (2001) Seasonal changes in zooplankton biomass and grazing in a temperate estuary, South Africa. Estuar Coast Shelf Sci 52:543-553

Froneman PW (2004) Food web dynamics in a temperate temporarily open/closed estuary (South Africa). Estuar Coast Shelf Sci 59:87-95

Frost BW (1972) Effects of size and concentration of food particles on the feeding behavior of the marine planktonic copepod Calanus Pacificus. Limnol Oceanogr 17:805-815

Fulmer JM (1997) Nutrient enrichment and nutrient input to Apalachicola Bay, Florida. MS thesis, Florida State University, FL

Gifford DJ, Caron DA (2000) Sampling, preservation, enumeration and biomass of marine protozooplankton. In: Harris RP, Wiebe PH, Lenz J, Skjoldal HR, Huntley M (eds) ICES Zooplankton Methodology Manual. Academic Press, San Diego, CA, p 193-221

Gifford DJ, Dagg M (1988) Feeding of the estuarine copepod Acartia tonsa Dana: carnivory vs. herbivory in natural microplankton assemblages. Bull Mar Sci 43:458-468

Hobro R, Willen E (1977) Phytoplankton countings. Intercalibration results and recommendations for routine work. Int Rev Hydrobiol 62:805-811

Jones RH, Flynn KJ (2005) Nutritional status and diet composition affect the value of diatoms as copepod prey. Science 307:1457-1459

Jonsson PR, Tiselius P (1990) Feeding behavior, prey detection and capture efficiency of the copepod Acartia tonsa feeding on planktonic ciliates. Mar Ecol Prog Ser 60:35-44

Kiørboe T (1989) Phytoplankton growth rate and nitrogen content: implications for feeding and fecundity in a herbivorous copepod. Mar Ecol Prog Ser 55:229-234

Kiørboe T, Møhlenberg F, Riisgard HU (1985a) In situ feeding rates of planktonic copepods: a comparison of four methods. J Exp Mar Biol Ecol 88:67-81

Kiørboe T, Møhlenberg F, Hamburger K (1985b) Bioenergetics of the planktonic copepod Acartia tonsa: relation between feeding, egg production and respiration, and composition of specific dynamic action. Mar Ecol Prog Ser 26:85-97

Klein Breteler WCM, Schogt N, Rampen S (2005) Effect of diatom nutrient limitation on copepod development: role of essential lipids. Mar Ecol Prog Ser 291:125-133

Kleppel GS (1992) Environmental regulation of feeding and egg production by Acartia tonsa off Southern California. Mar Biol 112:57-65 
Kleppel GS (1993) On the diets of calanoid copepods. Mar Ecol Prog Ser 99:183-195

Kleppel GS, Hazzard SE (2000) Diet and egg production of the copepod Acartia tonsa in Florida Bay. II. Role of the nutritional environment. Mar Biol 137:111-121

Kleppel GS, Burkart CA, Houchin L (1998) Nutrition and the regulation of egg production in the calanoid copepod Acartia tonsa. Limnol Oceanogr 43:1000-1007

Legendre L, Rassouladegan F (1995) Plankton and nutrient dynamics in marine waters. Ophelia 41:153-172

Li WKW, Glover HE, Morris I (1980) Physiology of carbon assimilation by Oscillatoria thiebatii in the Caribbean Sea. Limnol Oceanogr 25:447-456

Liu HB, Dagg M, Wu CJ, Chiang KP (2005) Mesozooplankton consumption of microplankton in the Mississippi River plume, with special emphasis on planktonic ciliates. Mar Ecol Prog Ser 286:133-144

Livingston RL (1984) The ecology of the Apalachicola Bay system: an estuarine profile. Report No. FWS/OBS 82/05, US Fish and Wildlife Service

Marcus NH (1991) Planktonic copepods in a sub-tropical estuary: seasonal patterns in the abundance of adults, copepodites, nauplii, and eggs in the sea bed. Biol Bull 181: 269-274

Marcus NH, Richmond C, Sedlacek C, Miller GA, Oppert C (2004) Impact of hypoxia on the survival, egg production and population dynamics of Acartia tonsa Dana. J Exp Mar Biol Ecol 301:111-128

Mauchline J (1998) The biology of calanoid copepods. In: Tyler PA (ed) Advances in marine biology, Vol 33. Academic Press, San Diego, CA

McCarthy JJ, Taylor WR, Taft JL (1977) Nitrogenous nutrition of the plankton in the Chesapeake Bay. I. Nutrient availability and phytoplankton preferences. Limnol Oceanog 22:996-1011

McLusky DS, Elliot M (eds) (2004) The estuarine ecosystem. Ecology, threats, and management. Oxford University Press, New York

Menden-Deuer S, Lessard EJ (2000) Carbon to volume relationships for dinoflagellates, diatoms, and other protist plankton. Limnol Oceanogr 45:569-579

Miller CB (2004) Biological Oceanography. Blackwell Publishing, Oxford

Miralto A, Barone G, Romano G, Poulet SA and 7 others (1999) The insidious effect of diatoms on copepod reproduction. Nature 402:173-176

Mortazavi B, Iverson RL, Huang WR, Lewis FG, Caffrey JM (2000a) Nitrogen budget of Apalachicola Bay, a bar-built estuary in the northeastern Gulf of Mexico. Mar Ecol Prog Ser 195:1-14

Mortazavi B, Iverson RL, Landing WM, Lewis FG, Huang WR (2000b) Control of phytoplankton production and biomass in a river-dominated estuary: Apalachicola Bay, Florida, USA. Mar Ecol Prog Ser 198:19-31

Mortazavi B, Iverson RL, Huang WR (2001) Dissolved organic nitrogen and nitrate in Apalachicola Bay, Florida: spatial distributions and monthly budgets. Mar Ecol Prog Ser 214: 79-91

Nejstgaard JC, Naustvoll LJ, Sazhin A (2001) Correcting for underestimation of microzooplankton grazing in bottle incubation experiments with mesozooplankton. Mar Ecol Prog Ser 221:59-75

Editorial responsibility: Howard Browman (Associate Editorin-Chief), Storebø, Norway
Postel L, Fock H, Hagen W (2000) Biomass and abundance. In: Harris RP, Wiebe PH, Lenz J, Skjoldal HR, Huntley M (eds) ICES zooplankton methodology manual. Academic Press, Amsterdam, p 83-192

Putland JN, Iverson RL (2007) Microzooplankton: major herbivores in an estuarine planktonic food web. Mar Ecol Prog Ser (in press)

Riegman R, Kuipers BR, Noordeloos AAM, Witte HJ (1993) Size differential control of phytoplankton and the structure of plankton communities. Neth J Sea Res 31:255-265

Rivkin RB (1985) Carbon-14 labelling patterns of individual marine phytoplankton from natural populations. Mar Biol 89:135-142

Rollwagen Bollens GC, Penry DL (2003) Feeding dynamics of Acartia spp. copepods in a large, temperate estuary (San Francisco Bay, CA). Mar Ecol Prog Ser 257:139-158

Runge JA, Roff JC (2000) The measurement of growth and reproductive rates. In: Harris RP, Wiebe $\mathrm{PH}$, Lenz J, Skjoldal HR, Huntley M (eds) ICES zooplankton methodology manual. Academic Press, San Diego, CA, p 407-415

Ryther JH (1969) Photosynthesis and fish production in the sea. Science 166:72-76

Sautour B, Artigas LF, Delmas D, Herbland A, Laborde P (2000) Grazing impact of micro- and mesozooplankton during a spring situation in coastal waters off the Gironde estuary. J Plankton Res 22:531-552

Sheridan PF (1978) Trophic relationships of dominant fishes in the Apalachicola Bay system (Florida). PhD thesis, Florida State University, FL

Sherr B, Caron DA, Sherr E (1993) Staining of heterotrophic protists for visualization via epifluorescence microscopy. In: Kemp PF, Sherr BF, Sherr EB, Cole JJ (eds) Handbook of methods in aquatic microbial ecology. Lewis Publishers, Boca Raton, FL, p 213-227

Smith PE, Counts RC, Clutter RI (1968) Changes in filtering efficiency of plankton nets due to clogging under tow. J Conserv 32:232-240

Sokal RR, Rohlf FJ (1995) Biometry. WH Freeman and Company, New York

Stoecker DK, Egloff DA (1987) Predation by Acartia tonsa Dana on planktonic ciliates and rotifers. J Exp Mar Biol Ecol 110:53-68

Straile D (1997) Gross growth efficiences of protozoan and metazoan zooplankton and their dependence on food concentration, predator-prey weight ratio, and taxonomic group. Limnol Oceanogr 42:1375-1385

Tang KW, Taal M (2005) Trophic modification of food quality by heterotrophic protists: species-specific effects on copepod egg production and egg hatching. J Exp Mar Biol Ecol 318:85-98

Welschmeyer N (1994) Fluorometric analysis of chlorophyll a in the presence of chlorophyll $b$ and pheopigments. Limnol Oceanogr 39:1985-1992

Wetzel RL, Likens GE (1991) Limnological analysis. SpringerVerlag, New York

White JR, Roman MR (1992) Egg production by the calanoid copepod Acartia tonsa in the mesohaline Chesapeake Bay: the importance of food resources and temperature. Mar Ecol Prog Ser 86:239-249

Wiebe $P$ (1972) A field investigation of the relationship between length of tow, size of net and sampling error. J Cons Int Explor Mer 34:268-275

Submitted: March 16, 2006; Accepted: October 19, 2006 Proofs received from author(s): May 23, 2007 